\title{
T-2 toxin induced Salmonella Typhimurium intoxication results in decreased Salmonella numbers in the cecum contents of pigs, despite marked effects on Salmonella-host cell interactions
}

\author{
Elin Verbrugghe ${ }^{1 *}$, Virginie Vandenbroucke ${ }^{2}$, Maarten Dhaenens ${ }^{3}$, Neil Shearer ${ }^{4}$, Joline Goossens ${ }^{2}$, \\ Sarah De Saeger ${ }^{5}$, Mia Eeckhout ${ }^{6}$, Katharina D'Herde ${ }^{7}$ Arthur Thompson ${ }^{4}$, Dieter Deforce ${ }^{3}$, Filip Boyen ${ }^{1}$, \\ Bregje Leyman ${ }^{1}$, Alexander Van Parys ${ }^{1}$, Patrick De Backer ${ }^{2}$, Freddy Haesebrouck', Siska Croubels ${ }^{2}$ and \\ Frank Pasmans ${ }^{1}$
}

\begin{abstract}
The mycotoxin T-2 toxin and Salmonella Typhimurium infections pose a significant threat to human and animal health. Interactions between both agents may result in a different outcome of the infection. Therefore, the aim of the presented study was to investigate the effects of low and relevant concentrations of T-2 toxin on the course of a Salmonella Typhimurium infection in pigs. We showed that the presence of 15 and $83 \mu \mathrm{g}$ T-2 toxin per $\mathrm{kg}$ feed significantly decreased the amount of Salmonella Typhimurium bacteria present in the cecum contents, and a tendency to a reduced colonization of the jejunum, ileum, cecum, colon and colon contents was noticed. In vitro, proteomic analysis of porcine enterocytes revealed that a very low concentration of T-2 toxin $(5 \mathrm{ng} / \mathrm{mL})$ affects the protein expression of mitochondrial, endoplasmatic reticulum and cytoskeleton associated proteins, proteins involved in protein synthesis and folding, RNA synthesis, mitogen-activated protein kinase signaling and regulatory processes. Similarly low concentrations $(1-100 \mathrm{ng} / \mathrm{mL})$ promoted the susceptibility of porcine macrophages and intestinal epithelial cells to Salmonella Typhimurium invasion, in a SPI-1 independent manner. Furthermore, T-2 toxin $(1-5 \mathrm{ng} / \mathrm{mL})$ promoted the translocation of Salmonella Typhimurium over an intestinal porcine epithelial cell monolayer. Although these findings may seem in favour of Salmonella Typhimurium, microarray analysis showed that T-2 toxin $(5 \mathrm{ng} / \mathrm{mL}$ ) causes an intoxication of Salmonella Typhimurium, represented by a reduced motility and a downregulation of metabolic and Salmonella Pathogenicity Island 1 genes. This study demonstrates marked interactions of T-2 toxin with Salmonella Typhimurium pathogenesis, resulting in bacterial intoxication.
\end{abstract}

\section{Introduction}

T-2 toxin is a type A trichothecene, produced by various Fusarium spp. such as Fusarium acuminatum, F. equiseti, F. poae and F. sporotrichioides [1]. In moderate climate regions of North America, Asia and Europe, these moulds are common contaminants of cereals such as wheat, barley, oats, maize and other crops for human

\footnotetext{
* Correspondence: Elin.verbrugghe@ugent.be

'Department of Pathology, Bacteriology and Avian Diseases, Faculty of

Veterinary Medicine, Ghent University, 9820 Merelbeke, Belgium

Full list of author information is available at the end of the article
}

and animal consumption [2]. Since mycotoxins are very stable under normal food processing conditions, T-2 toxin can end up in the food and feed. With T-2 toxin being the most acute toxic trichothecene [3], this mycotoxin may pose a threat to human and animal health around the world. Pigs appear to be one of the most sensitive species to Fusarium mycotoxins [4]. Moderate to high levels of T-2 toxin cause a variety of toxic effects including immunosuppression, feed refusal, vomiting, weight loss, reduced growth and skin lesions [5]. Only little information is available on in vivo effects from 
humans with known exposure to T-2 toxin. Wang et al. reported an outbreak of human toxicosis in China caused by moldy rice contaminated with T-2 toxin at concentrations ranging from 180 to $420 \mu \mathrm{g}$ T-2 toxin per $\mathrm{kg}$, and the main symptoms were nausea, vomiting, abdominal pain, thoracic stuffiness and diarrhea [6]. Furthermore, it is suggested that alimentary toxic aleukia (ATA), which occurred in the USSR in the period 1941-1947, is related to the presence of T-2 toxin producing Fusarium spp. in over-wintered grain. Clinical symptoms include inflammation of gastric and intestinal mucosa, leukopenia, hemorrhagic diathesis, granulopenia, bone marrow aplasia and sepsis [7]. Although a tolerable daily intake (TDI) value for the sum of T-2 toxin and HT-2 toxin of $100 \mathrm{ng} / \mathrm{kg}$ has been set by the European Union [8], control of exposure is limited since no maximum guidance limits for $\mathrm{T}-2$ toxin in food and feedstuff are yet established by the European Union. However, contamination of cereals with T-2 toxin is an emerging issue and concentrations up to $1810 \mu \mathrm{g}$ T-2 toxin per $\mathrm{kg}$ wheat have been reported in Germany [9].

Besides mycotoxins, Salmonella enterica subspecies enterica serovar Typhimurium (Salmonella Typhimurium) infections are a major issue in swine production and one of the major causes of foodborne salmonellosis in humans [10]. Pigs infected with Salmonella Typhimurium mostly carry this bacterium asymptomatically in their tonsils, gut and gut-associated lymphoid tissue for weeks or even months [11]. These carrier pigs excrete very low numbers of Salmonella and are difficult to distinguish from uninfected pigs. However, at slaughter they can be a source of environmental and carcass contamination, leading to higher numbers of foodborne Salmonella infections in humans. Although nontyphoidal Salmonella infections in humans mostly result in gastroenteritis, it is still a major cause of morbidity and mortality worldwide. It is estimated that nontyphoidal Salmonella infections result in 93.8 million illnesses globally each year, of which 80.3 million are foodborne, and 155000 result in death [12].

$\mathrm{T}-2$ toxin is rapidly absorbed in the small intestine [13] and affects the porcine and human innate immune system at various levels $[14,15]$. Since the pathogenesis of a Salmonella infection is characterized by a systemic and an enteric phase of infection, T-2 toxin might interfere with the pathogenesis of Salmonella Typhimurium. However, until now, there are no data available describing an interaction between low concentrations of T-2 toxin and the pathogenesis of a Salmonella Typhimurium infection in pigs. Only some scarce results have been reported of an altered susceptibility to intestinal infections after ingestion of sometimes high and even irrelevant concentrations of certain mycotoxins. Feeding pigs with $5 \mathrm{mg}$ $\mathrm{T}-2$ toxin per $\mathrm{kg}$ feed, resulted in a substantial increase in aerobic bacterial counts in the intestine [16]. Tai and Pestka showed that the oral exposure of mice to T-2 toxin could result in an impaired murine resistance to Salmonella Typhimurium [17]. Furthermore Oswald et al. showed that fumonisin B1 (FB1) increases the intestinal colonization by pathogenic Escherichia coli in pigs [18]. However, Tanguy et al. stated that feeding pigs with FB1 did not induce modifications in the number of Salmonella bacteria in the ileum, cecum and colon of pigs [19].

With T-2 toxin and Salmonella being two phenomenons to which pigs can be exposed during their lives, the aim of the presented study was to investigate the effects of low and in practice relevant concentrations of T-2 toxin on the course of a Salmonella Typhimurium infection in pigs and to elucidate if it alters bacterium-host cell interactions.

\section{Materials and methods Chemicals}

T-2 toxin (Sigma-Aldrich, Steinheim, Germany) stock solution of $5 \mathrm{mg} / \mathrm{mL}$ was prepared in ethanol and stored at $-20^{\circ} \mathrm{C}$. Serial dilutions of T-2 toxin were prepared in Luria-Bertani broth (LB, Sigma-Aldrich) or in the corresponding cell culture medium, depending on the experiment.

\section{Bacterial strains and growth conditions}

Salmonella Typhimurium strain 112910a, isolated from a pig stool sample and characterized previously by Boyen et al., was used as the wild type strain in which the spontaneous nalidixic acid resistant derivative strain (WTnal) was constructed [20]. The construction and characterization of a deletion mutant in the gene encoding the SPI-1 regulator HilA has been described before [21]. Unless otherwise stated, the bacteria were generally grown overnight (16 to $20 \mathrm{~h}$ ) as a stationary phase culture with aeration at $37^{\circ} \mathrm{C}$ in $5 \mathrm{~mL}$ of LB broth. To obtain highly invasive late logarithmic cultures for invasion assays, $2 \mu \mathrm{L}$ of a stationary phase culture were inoculated in $5 \mathrm{~mL} \mathrm{LB}$ broth and grown for $5 \mathrm{~h}$ at $37^{\circ} \mathrm{C}$ without aeration [22].

For oral inoculation of pigs, the WTnal was used to provide a selectable marker for identification of experimentally introduced bacteria when plating tonsillar, lymphoid, intestinal and faecal samples. The bacteria were grown for $16 \mathrm{~h}$ at $37^{\circ} \mathrm{C}$ in $5 \mathrm{~mL} \mathrm{LB}$ broth on a shaker, washed twice in Hank's buffered salt solution (HBSS, Gibco, Life Technologies, Paisley, Scotland) by centrifugation at $2300 \times g$ for $10 \mathrm{~min}$ at $4^{\circ} \mathrm{C}$ and finally diluted in HBSS to the appropriate concentration of $10^{7}$ colony forming units (CFU) per $\mathrm{mL}$. The number of viable Salmonella bacteria per $\mathrm{mL}$ inoculum was determined by plating 10-fold dilutions on Brilliant Green Agar (BGA, international medical 
products, Brussels, Belgium) supplemented with $20 \mu \mathrm{g} / \mathrm{mL}$ nalidixic acid $\left(\mathrm{BGA}^{\mathrm{NAL}}\right)$ for selective growth of the mutant strains.

\section{Experimental infection with Salmonella Typhimurium of pigs fed T-2 toxin- supplemented diets}

All animal experiments were carried out in strict accordance with the recommendations in the European Convention for the Protection of Vertebrate Animals used for Experimental and other Scientific Purposes. The experimental protocols and care of the animals were approved by the Ethics Committee of the Faculty of Veterinary Medicine, Ghent University (EC 2010/049 + expansion 2010/101).

\section{Experimental design}

Three-week-old piglets (commercial closed line based on Landrace) from a serologically Salmonella negative breeding herd (according to the Belgian Salmonella monitoring program) were used in this in vivo trial. The Salmonella-free status of the piglets was tested serologically using a commercially available Salmonella antibody test kit (IDEXX, Hoofddorp, The Netherlands), and bacteriologically via multiple faecal sampling. At arrival, the piglets were randomized into three groups of 5 piglets (Table 1) and each group was housed in separate isolation units at $26^{\circ} \mathrm{C}$ under natural day-night rhythm with ad libitum access to feed and water. The first 6 days after arrival, all piglets received a commercial blank piglet feed (DANIS, Koolskamp, Belgium) that contains all the nutrients for proper growth, as an acclimatisation period. The feed was free from mycotoxin-contamination, as determined by multi-mycotoxin liquid chromatography tandem mass spectrometry (LC-MS/MS) [23] and the composition of the feed is provided in the Additional file 1 . The acclimatisation period was followed by a feeding period of 23 days with the experimental feed diets that were prepared by adding T-2 toxin to the blank feed. The first group received ad libitum blank feed (control group), the second group received feed contaminated with $15 \mu \mathrm{g} / \mathrm{kg} \mathrm{T}-2$ toxin (15 ppb group) and the third group received feed contaminated with $83 \mu \mathrm{g} / \mathrm{kg}$ T-2 toxin (83 ppb group). These concentrations were chosen based on previous measurements of T-2 toxin contamination of feed [23]. After a feeding period of 18 days, the pigs were orally inoculated with $2 \times 10^{7} \mathrm{CFU}$ of Salmonella Typhimurium $\mathrm{WT}_{\text {nal. }}$. Five days after inoculation, the pigs were euthanized and samples of tonsils, ileocaecal lymph nodes, duodenum, jejunum, ileum, cecum, colon, contents of cecum and colon and rectal faeces were collected for bacteriological analysis to determine the number of Salmonella bacteria. To investigate the intestinal cytokine response, ileal fragments were immediately frozen in liquid nitrogen and stored at $-70^{\circ} \mathrm{C}$ until analysis. Furthermore, to determine the average weight gain (\%) of the pigs, the animals were individually weighed after the acclimatization period and, in order to exclude a possible effect of the Salmonella infection on the weight gain, after a feeding period of 18 days.

\section{Bacteriological analysis}

All tissues and samples were weighed and $10 \%(\mathrm{w} / \mathrm{v})$ suspensions were prepared in buffered peptone water (BPW, Oxoid, Basingstoke, United Kingdom). The samples were homogenized with a Colworth stomacher 400 (Seward and House, London, United Kingdom) and the number

Table 1 Distribution of the sexes of the pigs that received, during 18 days, blank feed (control group), feed contaminated with $15 \mu \mathrm{g}$ T-2 toxin per $\mathrm{kg}$ feed (15 ppb group) or feed contaminated with $83 \mu \mathrm{g}$ T-2 toxin per $\mathrm{kg}$ feed (83 ppb group), their respective weight at the beginning of the experiment and their average weight gain.

\begin{tabular}{|c|c|c|c|c|c|}
\hline & & $\begin{array}{l}\text { Distribution } \\
\text { of sexes }\end{array}$ & $\begin{array}{l}\text { Weight at beginning of the } \\
\text { experiment }(\mathrm{kg})\end{array}$ & $\begin{array}{l}\text { Average weight gain per } \\
\text { group per day (kg/day) }\end{array}$ & $\begin{array}{l}\text { Average weight gain during } \\
18 \text { days per group (\%) }\end{array}$ \\
\hline \multirow[t]{5}{*}{ control group } & piglet 1 & female & 6.5 & $0.326 \pm 0.08$ & $102 \pm 17.3$ \\
\hline & piglet 2 & female & 5.5 & & \\
\hline & piglet 3 & female & 5.5 & & \\
\hline & piglet 4 & male & 5.0 & & \\
\hline & piglet 5 & male & 6.0 & & \\
\hline \multirow[t]{5}{*}{15 ppb group } & piglet 6 & female & 4.5 & $0.322 \pm 0.08$ & $104 \pm 14.2$ \\
\hline & piglet 7 & male & 7.0 & & \\
\hline & piglet 8 & female & 5.0 & & \\
\hline & piglet 9 & male & 4.5 & & \\
\hline & piglet 10 & male & 7.0 & & \\
\hline \multirow[t]{5}{*}{83 ppb group } & piglet 11 & female & 5.5 & $0.239 \pm 0.04$ & $70.9 \pm 11.3^{*}$ \\
\hline & piglet 12 & male & 7.5 & & \\
\hline & piglet 13 & female & 6.0 & & \\
\hline & piglet 14 & male & 6.5 & & \\
\hline & piglet 15 & male & 5.0 & & \\
\hline
\end{tabular}

Superscript $(*)$ refers to a significant difference compared to the control group $(p<0.05)$. 
of Salmonella bacteria was determined by plating 10 -fold dilutions on $\mathrm{BGA}^{\mathrm{NAL}}$ plates. These were incubated for $16 \mathrm{~h}$ at $37^{\circ} \mathrm{C}$. The samples were pre-enriched for $16 \mathrm{~h}$ in $\mathrm{BPW}$ at $37^{\circ} \mathrm{C}$ and, if negative at direct plating, enriched for $16 \mathrm{~h}$ at $37^{\circ} \mathrm{C}$ in tetrathionate broth (Merck KGaA, Darmstadt, Germany) and plated again on BGA ${ }^{\text {NAL }}$. Samples that were negative after direct plating but positive after enrichment were presumed to contain 83 CFU per gram tissue or contents (detection limit for direct plating). Samples that remained negative after enrichment were presumed to be free of Salmonella in 1 gram tissue or contents and were assigned value " 1 " prior to log transformation. Subsequently the number of CFU for all samples was converted logarithmically prior to calculation of the average differences between the log10 values of the different groups and prior to statistical analysis.

\section{Intestinal cytokine response analysis}

Total RNA from the intestinal samples was isolated using RNAzol ${ }^{\circledR}$ RT (MRC Inc., Cincinnati, USA) according to the manufacturer's instructions. Extracted RNA was resuspended in $20 \mu \mathrm{L}$ ultra-pure water. The RNA concentration was measured by absorbance at $260 \mathrm{~nm}$ using a nanodrop spectrophotometer (Thermo Scientific, Wilmington, USA) and the integrity of the RNA samples was checked using an Experion RNA StdSens Analysis kit (Biorad Laboratories, Hercules, CA, USA). The construction of cDNA and real-time quantitative PCR analysis to quantify IL- $1 \beta$, IL-6, IL-8, IL-12, IL-18, TNF $\alpha$, IFN $\gamma$ and MCP-1, were carried out as described by Vandenbroucke et al. [24].

\section{Effects of T-2 toxin on host-pathogen interactions between Salmonella Typhimurium and porcine host cells Cytotoxicity of T-2 toxin towards Salmonella Typhimurium infected porcine macrophages and intestinal epithelial cells} It is possible that T-2 toxin increases the toxicity of Salmonella Typhimurium for host cells, resulting in an increased cell death. Therefore, the cytotoxic effect of T-2 toxin on Salmonella Typhimurium infected primary porcine alveolar macrophages (PAM) and intestinal porcine epithelial (IPEC-J2) cells was determined using the neutral red (3-amino-7-dimethylamino-2-methyl-phenazine hydrochloride) uptake assay [25]. Both cell cultures were isolated and cultured as previously described [26]. PAM were seeded in a 96-well microplate at a density of approximately $2 \times 10^{5}$ cells per well and were allowed to attach for $2 \mathrm{~h}$. The IPEC-J2 cells were seeded in a 96-well microplate at a density of approximately $2 \times 10^{4}$ cells per well and allowed to grow for either 24 h or 21 days, representing actively dividing and differentiated cells respectively. Subsequently, a Salmonella gentamicin protection invasion assay was performed as follows. The host cells were inoculated with Salmonella at a multiplicity of infection (MOI) of 10:1. To synchronize the infection, the inoculated multiwell plates were centrifuged at $365 \times g$ for $10 \mathrm{~min}$ and incubated for $30 \mathrm{~min}$ at $37^{\circ} \mathrm{C}$ under $5 \% \mathrm{CO}_{2}$. Subsequently, the cells were washed 3 times with Hank's buffered salt solution with $\mathrm{Ca}^{2+}$ and $\mathrm{Mg}^{2+}$ (HBSS+, Gibco) and fresh medium supplemented with $100 \mu \mathrm{g} / \mathrm{mL}$ gentamicin (Gibco) was added. Following a $1 \mathrm{~h}$ incubation, the medium was replaced by fresh medium containing $20 \mu \mathrm{g} /$ $\mathrm{mL}$ gentamicin whether or not supplemented with different concentrations of T-2 toxin, for $24 \mathrm{~h}$. PAM, actively dividing and differentiated IPEC-J2 cells were subjected to $\mathrm{T}-2$ toxin concentrations ranging from 0.250 to $10 \mathrm{ng} / \mathrm{mL}$, 0.500 to $10 \mathrm{ng} / \mathrm{mL}$ and 0.500 to $100 \mathrm{ng} / \mathrm{mL}$, respectively. To assess cytotoxicity, $150 \mu \mathrm{L}$ of freshly prepared neutral red solution ( $33 \mu \mathrm{g} / \mathrm{mL}$ in DMEM without phenol red), preheated to $37^{\circ} \mathrm{C}$, was added to each well and the plate was incubated at $37^{\circ} \mathrm{C}$ for an additional $2 \mathrm{~h}$. The cells were then washed twice with HBSS + and the dye was released from viable cells by adding $150 \mu \mathrm{L}$ of extracting solution ethanol/Milli-Q water/acetic acid, 50/49/1 (v/v/v) to each well. The plate was shaken for $10 \mathrm{~min}$ and the absorbance was determined at $540 \mathrm{~nm}$ using a microplate ELISA reader (Multiscan MS, Thermo Labsystems, Helsinki, Finland). The percentage of viable cells was calculated using the following formula:

$$
\% \text { cytotoxicity }=100 \times((a-b) /(c-b)) .
$$

Where $\mathrm{a}=\mathrm{OD}_{540}$ derived from the wells incubated with $\mathrm{T}-2$ toxin, $\mathrm{b}=\mathrm{OD}_{540}$ derived from blank wells, $\mathrm{c}=$ $\mathrm{OD}_{540}$ derived from untreated control wells.

Effect of T-2 toxin on the invasion and intracellular survival of Salmonella Typhimurium in porcine macrophages and intestinal epithelial cells

To examine whether the ability of Salmonella Typhimurium to invade and proliferate in PAM and IPEC-J2 cells was altered after exposure of these cells to T-2 toxin, invasion and intracellular survival assays were performed.

For the invasion assays, PAM and IPEC-J2 cells were seeded in 24-well plates at a density of approximately $5 \times$ $10^{5}$ and $10^{5}$ cells per well, respectively. PAM were allowed to attach for $2 \mathrm{~h}$ and IPEC-J2 cells were allowed to grow for either 24 h or 21 days. Subsequently, PAM and actively dividing and differentiated IPEC-J2 cells were exposed to different concentrations of $\mathrm{T}-2$ toxin ranging from 0.250 to $7.5 \mathrm{ng} / \mathrm{mL}, 0.500$ to $10 \mathrm{ng} / \mathrm{mL}$ and 0.500 to $100 \mathrm{ng} / \mathrm{mL}$, respectively. After $24 \mathrm{~h}$, a gentamicin protection assay was performed as mentioned above. In short, the cells were inoculated with Salmonella bacteria (WT or $\Delta$ hilA), whether or not grown in LB medium with T-2 toxin at concentrations ranging from 0.5 to $100 \mathrm{ng} / \mathrm{mL}$, at a MOI of 10:1. Subsequently, the cells were washed and fresh medium supplemented with $100 \mu \mathrm{g} / \mathrm{mL}$ gentamicin was added. After one hour, PAM and IPEC-J2 cells were 
washed 3 times and lysed for 10 min with $1 \%$ (v/v) Triton X-100 (Sigma-Aldrich) or $0.2 \%(\mathrm{w} / \mathrm{v})$ sodium deoxycholate (Sigma-Aldrich), respectively, and 10-fold dilutions were plated on BGA plates.

To assess intracellular growth, cells were seeded and inoculated with Salmonella Typhimurium as described in the invasion assay, but the medium containing $100 \mu \mathrm{g} / \mathrm{mL}$ gentamicin was replaced after $1 \mathrm{~h}$ incubation with fresh medium containing $20 \mu \mathrm{g} / \mathrm{mL}$ gentamicin, whether or not supplemented with different concentrations of T-2 toxin as mentioned above. The number of viable bacteria was assessed $24 \mathrm{~h}$ after infection.

\section{Effect of T-2 toxin on the translocation of Salmonella} Typhimurium through an intestinal epithelial cell layer

To examine whether T-2 toxin affects the transepithelial passage of Salmonella Typhimurium through IPEC-J2 cells, a translocation assay was performed. Prior to seeding IPEC-J2 cells, Transwell ${ }^{\circledR}$ polycarbonate membrane inserts with a pore size of $3.0 \mu \mathrm{m}$ and membrane diameter of $6.5 \mathrm{~mm}$ (Corning Costar Corp., Cambridge, MA, USA) were coated using PureCol bovine purified collagen (Inamed Biomaterials, Fremont, California, USA). Collagen working solution was made using a 1:100 dilution of Pure$\mathrm{Col}(2.9 \mathrm{mg} / \mathrm{mL})$ in $\mathrm{H} 2 \mathrm{O}$. Two hundred $\mu \mathrm{L}$ of the working collagen solution was added to each transwell and was allowed to air-dry in a laminar flow hood before being exposed to UV radiation for $20 \mathrm{~min}$. After coating, IPECJ2 cells were seeded on the apical side of these inserts at a density of $2 \times 10^{4}$ cells/insert, cell medium was refreshed every 3 days and cells were cultured for 21 days in order to differentiate, which was determined by a preliminary experiment (Additional file 2).

After 21 days, $200 \mu \mathrm{L}$ cell culture medium with T-2 toxin at concentrations of $0.750,1,2.5,4$ or $5 \mathrm{ng} / \mathrm{mL}$ was added to the apical side, while the basolateral side received $1 \mathrm{~mL}$ of blank culture medium. After $24 \mathrm{~h}$ of treatment with T-2 toxin, the Transwell ${ }^{\circledR}$ inserts were washed three times with HBSS + . Then, $5 \times 10^{6} \mathrm{CFU}$ of Salmonella Typhimurium were added to the apical compartment, suspended in IPEC-J2 medium without antibiotics, but supplemented with the respective concentrations of T-2 toxin. The basolateral compartment was filled with antibiotic-free IPEC-J2 medium. After 15, 30, 45 and $60 \mathrm{~min}$ at $37^{\circ} \mathrm{C}$ and $5 \% \mathrm{CO}_{2}$, the number of bacteria $(\mathrm{CFU} / \mathrm{mL})$ was determined in the basolateral compartment by plating 10-fold dilutions on BGA plates. In addition, transepithelial electrical resistance (TEER) measurements were performed before and after the incubation with T-2 toxin in order to evaluate the cell barrier integrity. This was done by transferring the inserts to an insert chamber (EndOhm6, World Precision Instruments, Sarasota, Florida, USA) and measuring the TEER via an epithelial voltohmmeter (World Precision Instruments).

\section{Effects of T-2 toxin on porcine host cells}

In order to elucidate the underlying mechanism of T-2 toxin induced increased invasion and translocation of Salmonella Typhimurium in and over porcine host cells, the effects of T-2 toxin on porcine host cells were assessed.

\section{Cytotoxicity of T-2 toxin towards porcine macrophages and intestinal epithelial cells}

In order to determine the toxic character of $\mathrm{T}-2$ toxin on porcine host cells and to determine whether it increases the toxicity of Salmonella Typhimurium for these porcine host cells, the cytotoxicity of T-2 toxin on uninfected PAM and IPEC cells was determined as described in the neutral red assay.

\section{Effect of T-2 toxin on porcine enterocyte ultrastructure}

Since the invasion assay pointed out that the T-2 toxin induced increased invasion of Salmonella Typhimurium was the highest in differentiated IPEC-J2 cells, transmission electron microscopy (TEM) was performed to characterize the effects of T-2 toxin on the ultrastructure of differentiated IPEC-J2 cells. The effect of $5 \mathrm{ng} / \mathrm{mL}$ T-2 toxin was investigated because this concentration significantly increases the invasion of the bacterium, without affecting the cell viability.

IPEC-J2 cells were seeded in 24-well plates at a density of approximately $10^{5}$ cells per well and were allowed to grow for 21 days. Samples for TEM were collected $24 \mathrm{~h}$ after treatment with $5 \mathrm{ng} / \mathrm{mL} \mathrm{T}-2$ toxin or blank medium as a control. After treatment with T-2 toxin, the wells were washed three times with $\mathrm{HBSS}+$, after which the cells were fixed in $4 \%$ formaldehyde in a $0.121 \mathrm{M} \mathrm{Na-caco-}$ dylate buffer ( $\mathrm{pH} 7.4$ ) containing $1 \%(\mathrm{w} / \mathrm{v}) \mathrm{CaCl}_{2}$ for $24 \mathrm{~h}$. After fixation, the wells were rinsed and subsequently dehydrated by adding successively 50\%, 70\%, 90\% and $100 \%$ ethanol to the wells. Next, the cells were embedded in LX-112 resin (Ladd Research Industries, Burlington, Vermont, USA) and cut with an ultratome (Ultracut E, Reichert Jung, Nussloch, Germany). The sections were examined under a Jeol EX II transmission electron microscope (Jeol, Tokyo, Japan) at $80 \mathrm{kV}$.

\section{Effect of T-2 toxin on the protein expression of porcine enterocytes}

Based on the results of the invasion assay, a comparative proteome study was conducted to reveal the effects of $5 \mathrm{ng} /$ $\mathrm{mL} \mathrm{T}-2$ toxin on the protein expression of differentiated IPEC-J2 cells. We used a gel-free approach called isobaric tags for relative and absolute quantification (iTRAQ) in which four different isobaric labels are used to tag N-termini and lysine side chains of four different samples with four different isobaric reagents. Upon collision-induced dissociation during MS/MS, the isobaric tags are released, which results in four unique reporter ions that are used to quantify the proteins in the four different samples [27]. 
Sample preparation IPEC-J2 cells were seeded in $175 \mathrm{~cm}^{2}$ cell culture flasks at a density of approximately $2 \times 10^{6}$ cells per flask and were allowed to grow for 21 days. Subsequently, IPEC-J2 cells were washed 3 times with HBSS + and either incubated with $5 \mathrm{ng} / \mathrm{mL} \mathrm{T-2}$ toxin or left untreated. After $24 \mathrm{~h}$, the cells were washed 3 times with HBSS + and were scraped off the bottom of the flask using a cell scraper. After washing the cells by centrifugation at $2300 \times g$ for $10 \mathrm{~min}$ at $4{ }^{\circ} \mathrm{C}$, they were finally resuspended in $500 \mu \mathrm{L}$ lysis buffer containing $40 \mathrm{mM}$ Tris (hydoxymethyl)aminomethane hydrochloride (Tris, SigmaAldrich), a cocktail of protease inhibitors (PIs; SigmaAldrich) and phosphatase inhibitors (PPI, Sigma-Aldrich), $172.6 \mathrm{U} / \mathrm{mL}$ deoxyribonuclease I (DNase I, Invitrogen, USA), $100 \mathrm{mg} / \mathrm{mL}$ ribonuclease A (RNase A, Qiagen, Venlo, The Netherlands) and 2\% (v/v) tributylphosphine (TBP, Sigma-Aldrich). The cells were sonicated (6 times 30 s), using an ultrasonic processor XL 2015 (Misonix, Farmingdale, New York, USA), followed by centrifugation at $17968 \times g$ for $10 \mathrm{~min}$. The supernatant was held on ice until further use and the pellet was dissolved and sonicated (6 times $30 \mathrm{~s}$ ), in reagent 3 of the Ready Prep Sequential extraction kit (Bio-Rad, Hercules, CA, USA). This was centrifugated at $17968 \times g$ for $10 \mathrm{~min}$. Both supernatants were combined and a buffer switch to $0.01 \%$ (w/v) SDS in $\mathrm{H}_{2} \mathrm{O}$ was performed using a Vivaspin column (5000 molecular weight cut off Hydrosarts, Sartorius, Germany). Protein concentration was determined using the Bradford Protein Assay (Thermo Fisher Scientific, Rockford, USA) according to the manufacturer's instructions.

Trypsin digest and iTRAQ labeling Digest and labeling of the samples $(100 \mu \mathrm{g}$ proteins per sample) with iTRAQ reagents was performed according to the manufacturer's guidelines (AB Sciex, Foster City, CA, USA). Individual samples of T-2 toxin treated or untreated IPEC-J2 cells were analyzed in the same run, making pairwise comparisons possible and minimizing technical variation. Each condition was run in duplicate using different labels of the four-plex labeling kit. The experiment was conducted in twofold and the labeling of the samples was as follows: run 1 (untreated IPEC-J2 cells sample 1: 114 - untreated IPEC-J2 cells sample 2: 115 treated IPEC-J2 cells sample 1: 116 - treated IPEC-J2 cells sample 2: 117) - run 2 (untreated IPECJ-2 cells sample 3: 114 - untreated IPEC-J2 cells sample 4: 115 treated IPEC-J2 cells sample 3: 116 - treated IPEC-J2 cells sample $4: 117)$. After labeling, $6 \mu \mathrm{L}$ of a $5 \%(\mathrm{v} / \mathrm{v})$ hydroxylamine solution was added to hydrolyze unreacted label and after incubation at room temperature for $5 \mathrm{~min}$, the samples were pooled, dried and resuspended in $5 \mathrm{mM} \mathrm{KH}_{2} \mathrm{PO}_{4}(15 \%$ (v/v) acetonitrile) (pH 2.7). The combined set of samples was first purified on ICAT SCX cartridges, desalted on a C18 trap column and finally fractionated using SCX chromatography.
Each fraction was analyzed by nano LC-MS/MS as described by Bijttebier et al. [28].

Data analysis With no full pig protein database available, different search parameters and databases, both EST and protein, were validated to obtain maximum spectrum annotation. Best results (39\% of spectra annotated above homology threshold with a $3.71 \%$ false discovery rate in the decoy database) were obtained when searching NCBI Mammalia. For quantification, data quality was validated using ROVER [29]. Based on this validation a combined approach was used to define recurrently different expression patterns. In a first approach, the four ratios that can be derived from each run $(114 / 116,115 / 117,114 / 117$ and 115/116) were logtransformed and a $t$-test was used to isolate protein ratios significantly different from 0 in each run. In a second approach, the two runs were merged into one file and the 114/116 and 115/117 ratios of each run were log-transformed and these ratios were multiplied $\left(\log { }^{*} \log \right)$. Proteins with recurrent up- or downregulation result in positive $\log * \log$ protein ratios and those $>0.01$ were retained and listed. Proteins that were present in both lists were considered unequivocally differentially expressed. This combined approach allows defining proteins with relatively low, but recurrent expressional differences.

\section{Effect of T-2 toxin on the growth, gene expression and motility of Salmonella Typhimurium}

Not only porcine host cells, but also Salmonella bacteria come in contact with T-2 toxin. Therefore, it is possible that T-2 toxin affects the bacterium and by doing so, alters the pathogenesis of a Salmonella Typhimurium infection in pigs.

\section{Effect of T-2 toxin on the gene expression of Salmonella Typhimurium}

To test whether T-2 toxin affects the gene expression of Salmonella Typhimurium, a microarray analysis was performed on RNA isolated from cultures of Salmonella Typhimurium grown for 5 hours to a logarithmic phase in the presence or absence of $5 \mathrm{ng} / \mathrm{mL}$ of $\mathrm{T}-2$ toxin.

Two OD600 units were harvested and RNA was extracted and purified using the SV Total RNA Isolation Kit (Promega Benelux bv, Leiden, The Netherlands) according to manufacturers' instructions. The quality and purity of the isolated RNA was determined using a Nanodrop spectrophotometer and Experion RNA StdSens Analysis kit (Biorad). The SALSA microarrays and protocols for RNA labeling, microarray hybridization and subsequent data acquisition have been described previously [30]. RNA $(10 \mu \mathrm{g})$ from 3 independent biological replicates of T-2 toxin treated and untreated (control) logarithmic phase cultures was labeled with $\mathrm{Cy} 5 \mathrm{dCTP}$ and 
hybridized to SALSA microarrays with $400 \mathrm{ng}$ of Cy3 dCTP labeled gDNA, as a common reference.

Genes were assessed to be statistically significantly differently expressed between the T-2 toxin treated and untreated controls by an analysis of variance test with a Benjamini and Hochberg false discovery rate of 0.05 and with a 1.5-fold change in the expression level.

The microarray data discussed in this publication are MIAME compliant and have been deposited in NCBI's Gene Expression Omnibus [31] and are accessible through GEO Series accession number GSE30925 [32].

\section{Effect of T-2 toxin on the growth of Salmonella}

\section{Typhimurium}

The effect of T-2 toxin $(0,0.04,0.31,2.5$ and $20 \mu \mathrm{g} / \mathrm{mL})$ on the growth of Salmonella Typhimurium was examined during $24 \mathrm{~h}$. For this purpose, Salmonella Typhimurium was grown in LB broth whether or not supplemented with $\mathrm{T}-2$ toxin. The number of $\mathrm{CFU} / \mathrm{mL}$ was determined at different time points $(t=0,3,6,8$ and $24 \mathrm{~h})$ by titration of 10 -fold dilutions of the bacterial suspensions on BGA.

\section{Effect of T-2 toxin on the motility of Salmonella}

\section{Typhimurium}

One $\mu \mathrm{L}$ of an overnight culture of Salmonella Typhimurium was spotted in the middle of a swim plate (Difco Nutrient Broth (Becton, Dickinson and Company, Sparks, USA), $0.5 \%(\mathrm{w} / \mathrm{v})$ glucose, $0.25 \%$ agar), whether or not supplemented with T-2 toxin $(0,100,500,1000 \mathrm{ng} / \mathrm{mL})$. The plates were allowed to dry for $1 \mathrm{~h}$ at room temperature, after which they were incubated at $37^{\circ} \mathrm{C}$ for $16 \mathrm{~h}$.

\section{Statistical analysis}

All in vitro experiments were conducted in triplicate with 3 repeats per experiment, unless otherwise stated. All statistical analyses were performed using SPSS version 19 (SPSS Inc., Chicago, IL, USA). Normally distributed data were analyzed using unpaired Student's $t$-test or one-way ANOVA to address the significance of difference between mean values with significance set at $p \leq 0.05$. Bonferroni as post hoc test was used when equal variances were assessed. If equal variances were not assessed, the data were analyzed using Dunnett's T3 test. Not normally distributed data were analyzed using the non parametric Kruskal-Wallis analysis, followed by a Mann-Whitney $U$ test.

\section{Results}

T-2 toxin decreases the amount of Salmonella Typhimurium bacteria present in the cecum contents of pigs and causes a reduction in weight gain

The presented study shows the effects of low and relevant concentrations of T-2 toxin on the course of a Salmonella Typhimurium infection in pigs. Animals that received feed contaminated with $15 \mu \mathrm{g}$ or $83 \mu \mathrm{g}$ T-2 toxin per $\mathrm{kg}$ feed for 23 days had lower numbers of Salmonella Typhimurium per gram in their bowel contents and organs in comparison to the control group that received non-contaminated feed for 23 days. As illustrated in Figure 1, this decrease was significant in the cecum contents for both the $15 \mathrm{ppb}$ and $83 \mathrm{ppb}$ group ( $p=0.001$ and $p=0.011$, respectively). A tendency to reduced colonization of the jejunum, ileum, cecum, colon and colon contents was noticed, although not significantly.

As shown in Table 1 the addition of $83 \mu \mathrm{g} \mathrm{T}-2$ toxin per $\mathrm{kg}$ feed resulted in a significantly reduced weight gain in comparison to the control group that had a mean weight gain $(\%) \pm$ standard deviation, during 18 days, of $102.1 \pm$ $17.3(p=0.016)$. Pigs that were fed 15 or $83 \mu g$ T-2 toxin per $\mathrm{kg}$ feed, for 18 days had a mean weight gain (\%) \pm standard deviation of $104.4 \pm 14.2$ and $70.9 \pm 11.3$, respectively. This corresponds to a mean weight gain \pm standard deviation of $0.326 \pm 0.08 \mathrm{~kg}$ per day for the control group, $0.322 \pm 0.08 \mathrm{~kg}$ per day for the $15 \mathrm{ppb}$ group and $0.239 \pm$ $0.04 \mathrm{~kg}$ per day for the $83 \mathrm{ppb}$ group.

\section{The addition of $\mathrm{T}-2$ toxin $(15 \mu \mathrm{g} / \mathrm{kg})$ to the feed causes a} decreased expression of IL-1 $\beta$

The effect of a 23 day feeding period with $15 \mu \mathrm{g}$ or $83 \mu \mathrm{g}$ of $\mathrm{T}-2$ toxin per $\mathrm{kg}$ feed on the intestinal mRNA expression levels of the cytokines (IL-1 $\beta$, IL-6, IL-12, IL-18, IFN $\gamma$ and TNF $\alpha$ ) and chemokines (IL-8 and MCP-1) was examined 5 days post inoculation with Salmonella Typhimurium. The results are illustrated in Figure 2. A significant decreased fold-difference of mRNA expression \pm standard deviation of pigs exposed to $15 \mu \mathrm{g}$ T-2 toxin per $\mathrm{kg}$ feed was noticed compared to the Salmonella Typhimurium positive control pigs for IL-1 $(0.31 \pm 0.24)(p=0.027)$.

\section{T-2 toxin is cytotoxic to porcine macrophages and intestinal epithelial cells}

The cytotoxic effect of T-2 toxin on PAM, undifferentiated and differentiated IPEC-J2 cells as determined using the neutral red assay, is shown in Figure 3. The viability of both uninfected and infected PAM, undifferentiated and differentiated IPEC-J2 cells was significantly decreased by exposure to concentrations of T-2 toxin $\geq 1 \mathrm{ng} / \mathrm{mL}, \geq 2.5$ $\mathrm{ng} / \mathrm{mL}$ and $\geq 15 \mathrm{ng} / \mathrm{mL}$, respectively. IC50 values of T-2 toxin for the different cell types were determined by linear regression and are presented in Table 2.

\section{Treatment of porcine macrophages and intestinal epithelial cells with T-2 toxin promotes the invasion of Salmonella Typhimurium}

Altered host-pathogen interactions between Salmonella Typhimurium and porcine host cells could account for the reduced numbers of Salmonella Typhimurium 


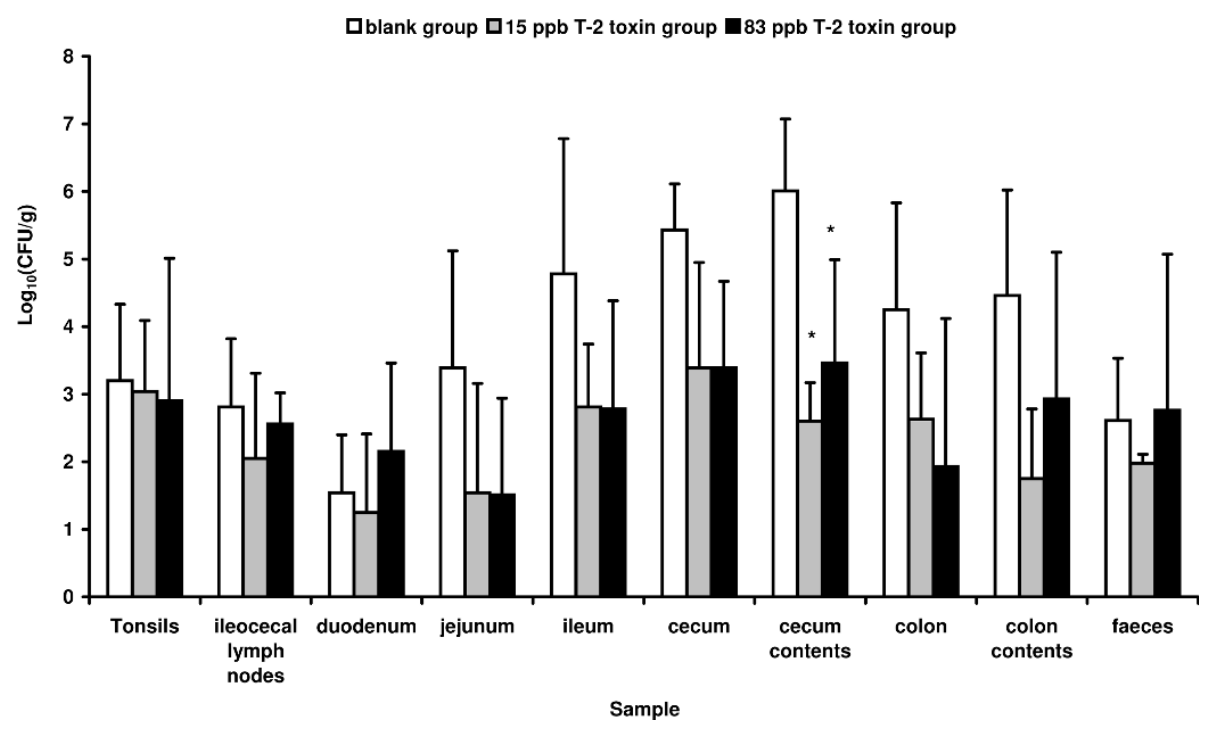

Figure 1 Effect of T-2 toxin on the colonization by Salmonella Typhimurium in pigs. Recovery of Salmonella Typhimurium bacteria from various organs and gut contents of pigs that received, during 23 days, blank feed (control group, white bars), feed contaminated with $15 \mu \mathrm{g} T-2$ toxin per kg feed (15 ppb group, grey bars) or feed contaminated with $83 \mu \mathrm{g}$ T-2 toxin per kg feed (83 ppb group, black bars), respectively. Five days after inoculation with $2 \times 10^{7}$ CFU of Salmonella Typhimurium, the pigs were euthanized and the log 10 value of the ratio of CFU per gram sample is given as the mean + standard deviation. Superscript $\left(^{*}\right)$ refers to a significant difference compared to the control group $(p<0.05)$.

present in the cecum contents. Therefore, the effect of $\mathrm{T}$ 2 toxin on host-pathogen interactions was investigated. The results of the invasion and intracellular survival assays of Salmonella Typhimurium in PAM, undifferentiated and differentiated IPEC-J2 cells with or without exposure to T-2 toxin are summarized in Figure 4.

The invasion of Salmonella Typhimurium was higher in PAM, undifferentiated and differentiated IPEC-J2 cells that were treated with T-2 toxin, for $24 \mathrm{~h}$, in comparison to non-treated cells. Exposure of PAM, undifferentiated and differentiated IPEC-J2 cells to T-2 toxin concentrations of 1,5 and $\geq 2.5 \mathrm{ng} / \mathrm{mL}$, respectively, led to a significant increase in the number of intracellular Salmonella Typhimurium bacteria. Due to the toxicity of T-2 toxin, exposure of PAM to T-2 toxin concentrations $\geq 7.5 \mathrm{ng} /$ $\mathrm{mL}$, resulted in a significant decrease in the number of intracellular bacteria. As shown in Figure 5, similar results were obtained using the deletion mutant $\Delta$ hilA, where a significant increased invasion was seen at $\mathrm{T}-2$ toxin concentrations $>5 \mathrm{ng} / \mathrm{mL}$.

A $24 \mathrm{~h}$ treatment of Salmonella infected PAM, undifferentiated and differentiated IPEC-J2 cells with non-cytotoxic concentrations of T-2 toxin, did not affect the intracellular proliferation of Salmonella Typhimurium in these cells. However, treatment with toxic concentrations of T-2 toxin resulted in a significantly decreased survival of Salmonella Typhimurium in PAM and undifferentiated IPEC-J2 cells at T-2 toxin concentrations $\geq 5 \mathrm{ng} / \mathrm{mL} \mathrm{T-2}$ toxin and in differentiated IPEC-J2 cells at concentrations $\geq 100 \mathrm{ng} / \mathrm{mL}$ T-2 toxin.
$\mathrm{T}-2$ toxin promotes the transepithelial passage of Salmonella Typhimurium through the intestinal epithelium

The passage of Salmonella Typhimurium through 21-daysold IPEC-J2 cells treated for $24 \mathrm{~h}$ with non-cytotoxic concentrations of T-2 toxin varying from 0.750 to $5 \mathrm{ng} / \mathrm{mL}$ is shown in Figure 6. Already after $30 \mathrm{~min}$, treatment of the IPEC-J2 cell monolayer with T-2 toxin concentrations $\geq 1$ $\mathrm{ng} / \mathrm{mL}$ resulted in a significant increase in the number of translocated bacteria in comparison to non-treated IPEC$\mathrm{J} 2$ cells. Exposure to concentrations of T-2 toxin varying from 0.750 to $5 \mathrm{ng} / \mathrm{mL}$, for $24 \mathrm{~h}$, did not lead to a decrease in TEER (Additional file 3) indicating no loss of integrity of the epithelial monolayer and suggesting an increased transcellular passage of the bacteria.

\section{T-2 toxin affects the protein expression of differentiated IPEC-J2 cells at a concentration that does not cause morphological changes}

In order to elucidate the possible mechanism of the T-2 toxin increased invasion in differentiated IPEC-J2 cells, iTRAQ analysis was performed on T-2 toxin treated porcine cells. Based on the invasion assay results, we opted to investigate the effect of T-2 toxin at a concentration of $5 \mathrm{ng} / \mathrm{mL}$ on differentiated IPEC-J2 cells. Peptides from trypsin digested proteins were labeled with isobaric mass tag labels and analyzed by 2-D LC-MS/MS. Collisioninduced dissociation results in the release of these isobaric tags, which allows relative quantification of the peptides. A broad comparison between $5 \mathrm{ng} / \mathrm{mL} \mathrm{T}-2$ toxin treated and 


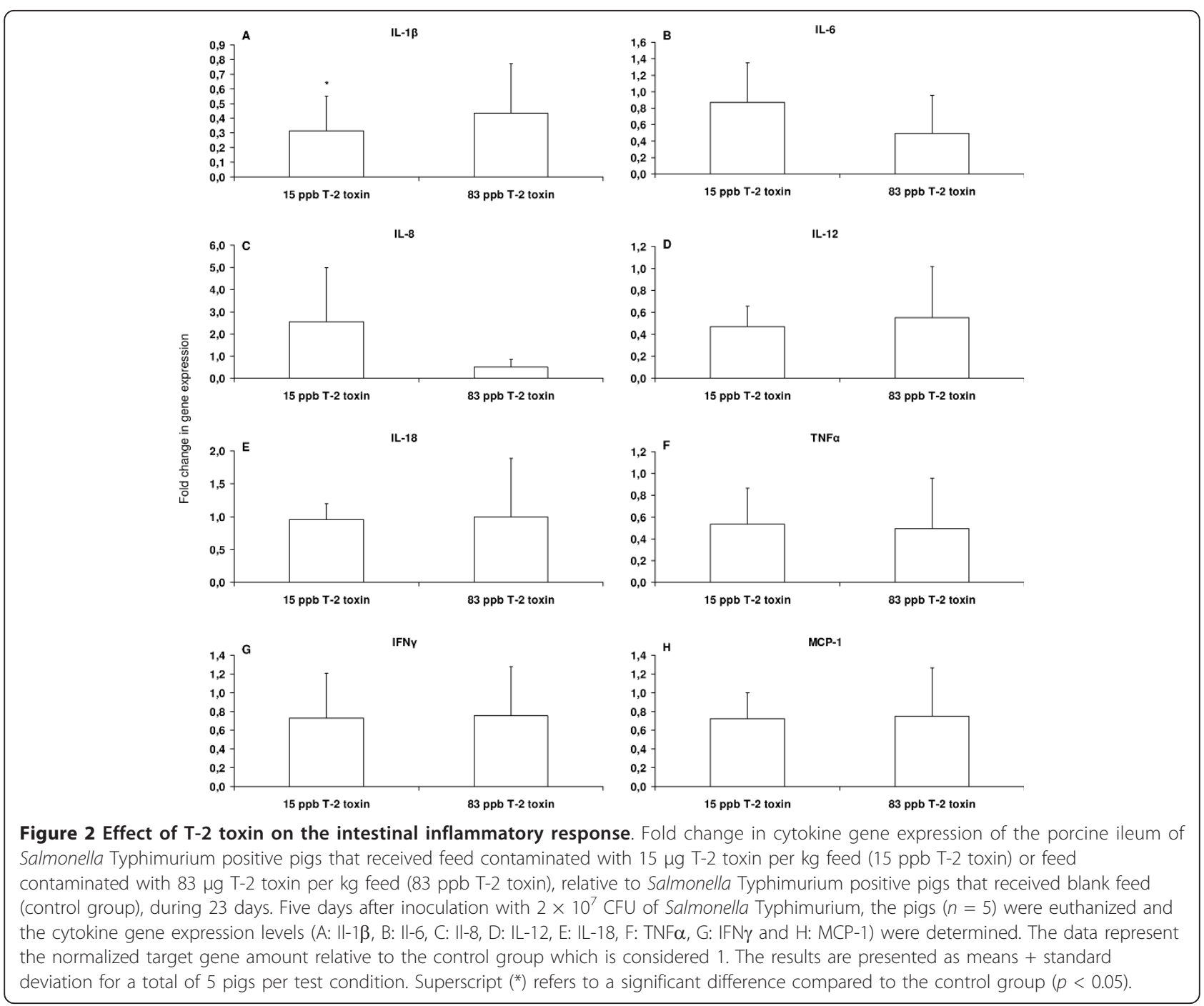

untreated differentiated IPEC-J2 cells, resulted in the identification of 21 proteins with relatively low, but recurrent expressional differences, as shown in Table 3. Eight of these proteins showed higher levels in untreated IPEC-J2 cells, whereas 13 of them were more abundant in T-2 toxin treated IPEC-J2 cells.

Differentially expressed proteins identified in T-2 toxin $(5 \mathrm{ng} / \mathrm{mL})$ treated IPEC-J2 cells in comparison to untreated IPEC-J2 cells by use of iTRAQ analysis coupled to 2-D LC-MS/MS. Superscript (*) refers to the protein description according to the UniProtKB/Swiss-Prot protein sequence database [33]

Proteomic analysis established a T-2 toxin induced upregulation of proteins involved in ribosome biogenesis [34], protein synthesis and folding [35,36], or c-Jun NTerminal kinase signalling [37], respectively predicted nucleolin-related protein isoform 3, elongation factor 1-beta, peptidyl-prolyl cis-trans isomerase A and glutathione S-transferase P. Furthermore, T-2 toxin increased the expression of pre-mRNA splicing factor heterogeneous nuclear ribonucleoprotein F, 14-3-3 sigma, branched-chain-amino-acid aminotransferase, heat shock protein 60 , heat shock protein 10 and thioredoxin-related transmembrane protein 1 , highlighting the toxic character of $5 \mathrm{ng} / \mathrm{mL} \mathrm{T}-2$ toxin. In contrast, T-2 toxin caused a decreased expression of proteins involved in membrane functions, mitochondrial proteins and endoplasmatic reticulum (ER) related proteins, namely annexin A4, cytochrome c oxidase subunit VIIc, chain A mitochondrial F1-ATPase complexed with aurovertin B, S-transferase 3 and S100-A16. These are involved in membrane bilayer function [38], mitochondrial electron transport [39], adenosine triphosphate (ATP) production [40], the cellular defense against oxygen-free radicals [41] or $\mathrm{Ca}^{2+}$ homeostasis, cell proliferation, migration, differentiation, apoptosis and transcription $[42,43]$, respectively. Moreover, T-2 toxin affects the expression of cytoskeleton associated proteins. It causes a decreased 


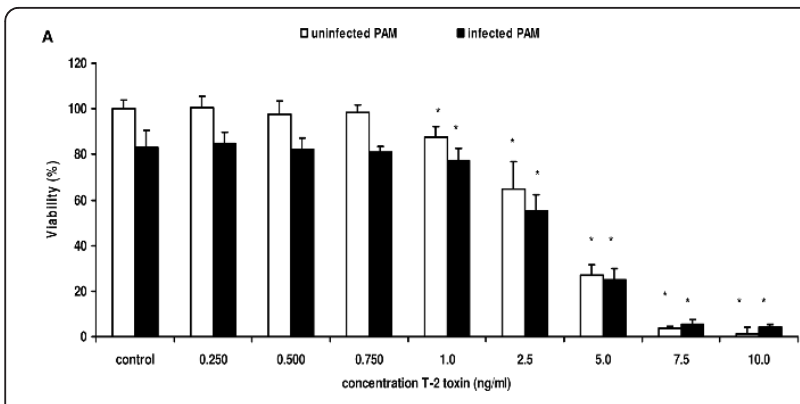

B

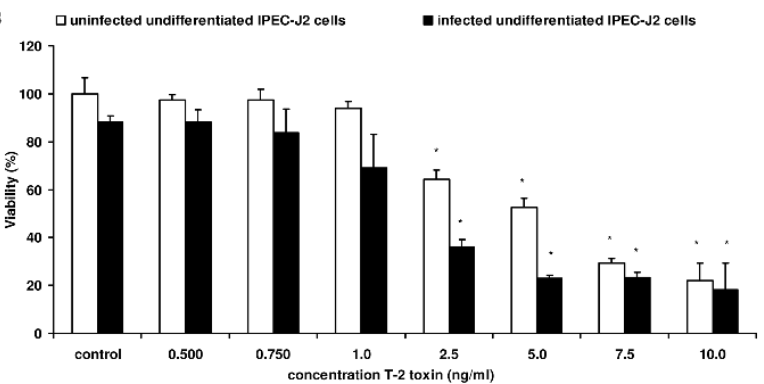

C

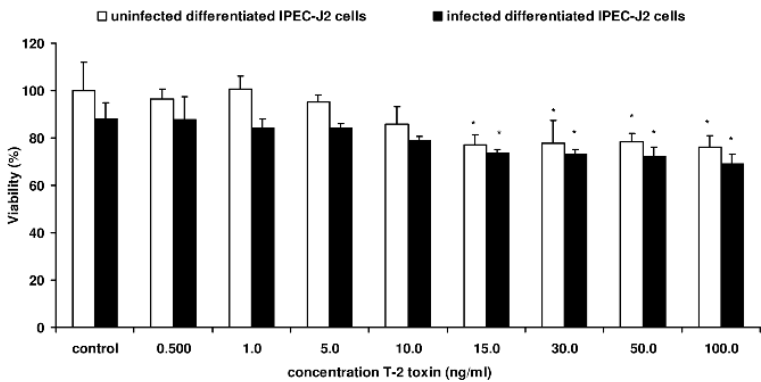

Figure 3 The effect of T-2 toxin on the cell viability. Percentage viability (\%) of Salmonella Typhimurium infected and uninfected (A) PAM exposed to different concentrations of T-2 toxin (0.250-10 ng/ $\mathrm{mL}),(\mathbf{B})$ undifferentiated IPEC-J2 cells exposed to different concentrations of T-2 toxin (0.500-10 ng/mL), (C) differentiated IPECJ2 cells exposed to different concentrations of T-2 toxin (0.500-100 $\mathrm{ng} / \mathrm{mL}$ ). Twenty-four hours after incubation with T-2 toxin, the cytotoxic effect was determined by neutral red assay. Results represent the means of 3 independent experiments conducted in triplicate and their standard deviation. Superscript $\left(^{*}\right)$ refers to a significant difference compared to the control group $(p<0.05)$

Table 2 IC50 values of T-2 toxin for PAM, undifferentiated and differentiated IPEC-J2 cells, either or not infected with Salmonella Typhimurium.

\begin{tabular}{ll}
\hline Cell type & $\begin{array}{l}\text { T-2 toxin concentration } \\
(\mathbf{n g} / \mathbf{m L})\end{array}$ \\
\hline Uninfected PAM & 4.3 \\
Infected PAM & 4.4 \\
Uninfected undifferentiated IPEC-J2 & 5.7 \\
cells & \\
Infected undifferentiated IPEC-J2 cells & 4.7 \\
Uninfected differentiated IPEC-J2 cells & 185 \\
Infected differentiated IPEC-J2 cells & 212.8 \\
\hline
\end{tabular}

expression of cytokeratin 18, myristoylated alanine-rich C-kinase substrate and putative beta-actin and an increased expression of thymosin beta-10, cysteine and glycine-rich protein 1 isoform 1 and profiling. Generally, these data showed that even a low concentration of $5 \mathrm{ng} /$ $\mathrm{mL} \mathrm{T}-2$ toxin damages the porcine enterocyte and affects cytoskeletal proteins. TEM pointed out that these changes in protein expression are not correlated with morphological changes (Figure 7).

T-2 toxin does not affect the growth, but decreases the motility and invasiveness of Salmonella Typhimurium Preliminary experiments showed that T-2 toxin up to 20 $\mu \mathrm{g} / \mathrm{mL}$ had no observable effect on the growth of Salmonella Typhimurium (Additional file 4). In order to look further for any possible effects of T-2 toxin on Salmonella Typhimurium, a microarray study was carried out with RNA isolated from logarithmic phase cultures grown for $5 \mathrm{~h}$ in the presence or absence of $5 \mathrm{ng} / \mathrm{mL}$ $\mathrm{T}-2$ toxin. It was found that expression of 262 genes was repressed and 352 genes induced following exposure to T-2 toxin (Additional file 5 and Additional file 6). In general, exposure of Salmonella Typhimurium to $\mathrm{T}-2$ toxin resulted in a small but significant reduction in the expression of key metabolic genes including 8 glycolytic genes, and genes encoding cytochrome o and $\mathrm{d}$ terminal oxidases, succinate dehydrogenase, NADH dehydrogenase and ATP synthase. Similarly, T-2 toxin exposure resulted in reduced expression of genes encoding both 30s and 50s ribosomal proteins. In addition, it was noted that expression of 5 flagella biosynthesis genes was reduced as was expression of 16 of the Salmonella Pathogenicity Island 1 (SPI-1) genes. Consistent with the observed reduction in flagella gene expression, motility of Salmonella Typhimurium on swarm plates was found to be reduced by $\mathrm{T}-2$ toxin in a dose dependent manner, however at concentrations of T-2 toxin $\geq 100 \mathrm{ng} / \mathrm{mL}$ (Figure 8). Furthermore, in line with the reduced expression of the Salmonella SPI-1 genes, concentrations of $\mathrm{T}-2$ toxin $\geq 10 \mathrm{ng} / \mathrm{mL}$ significantly decreased the invasion capacity of Salmonella Typhimurium in differentiated IPEC-J2 cells (Figure 9a). However, if both Salmonella bacteria and differentiated IPEC-J2 cells are exposed to T-2 toxin $(\geq 2.5 \mathrm{ng} / \mathrm{mL})$, increased invasion in differentiated IPEC-J2 cells was observed (Figure 9b).

Of the genes found to be upregulated following T-2 toxin exposure many (36) were related to cell-envelope and outer membrane biogenesis suggesting that the toxin may cause membrane or cell wall damage. Expression of 61 genes involved in signal transduction and transcription was increased, suggesting the bacteria were undergoing a global stress response to deal with the toxic insult. Consistent with this, both the $\operatorname{emr} A B$ and $b c r$ 

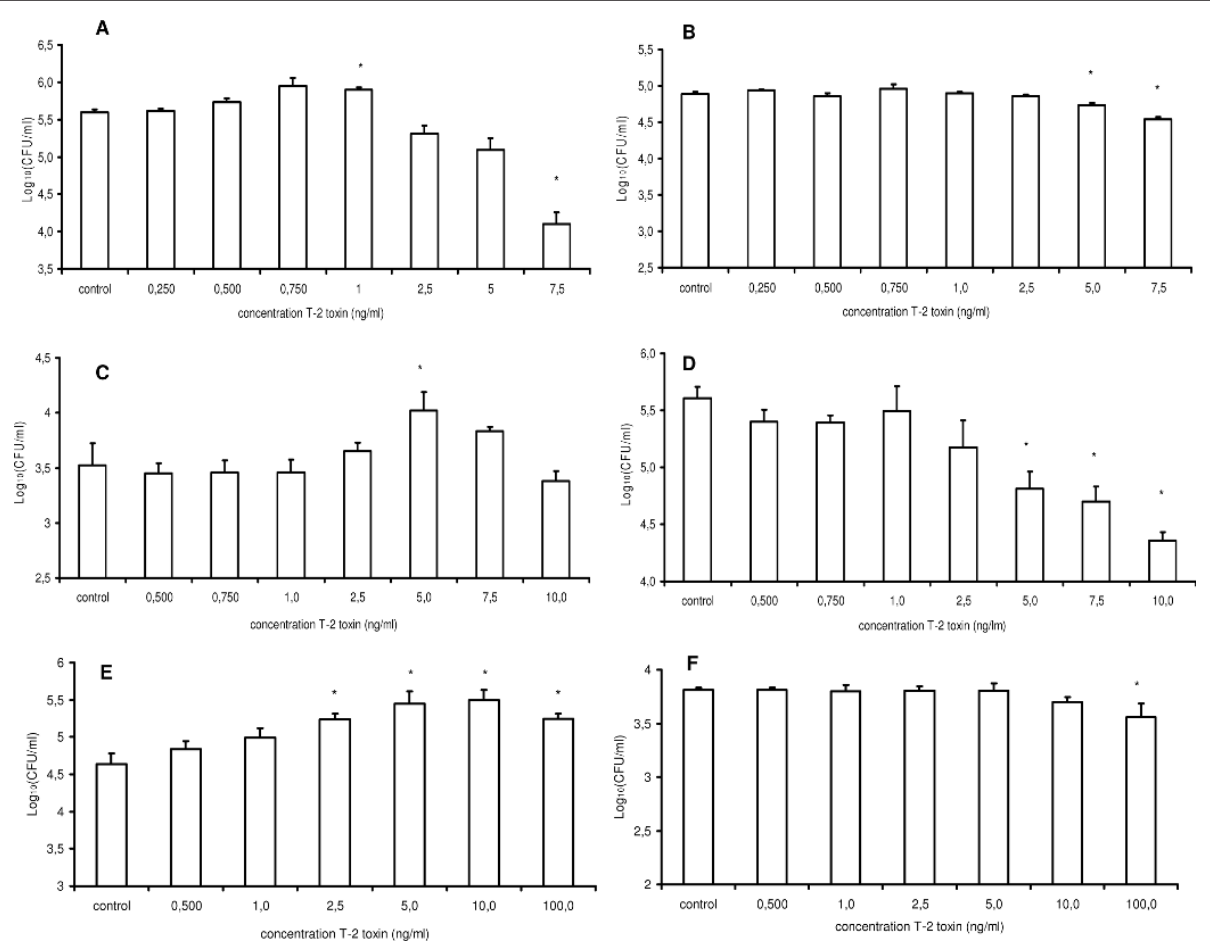

Figure 4 Effect of T-2 toxin treatment of porcine cells on the invasion and intracellular proliferation of Salmonella Typhimurium. The invasiveness is shown of Salmonella Typhimurium in (A) PAM, (C) undifferentiated and (E) differentiated IPEC-J2 cells whether or not exposed to different concentrations of T-2 toxin (0.250-7.5, 0.500-10 or $0.500100 \mathrm{ng} / \mathrm{mL}$ respectively). The survival of Salmonella Typhimurium, $24 \mathrm{~h}$ after invasion in (B) PAM, (D) undifferentiated and (F) differentiated IPEC-J2 cells whether or not exposed to different concentrations of T-2 toxin (0.250-7.5, $0.500-10$ or $0.500-100 \mathrm{ng} / \mathrm{mL}$ respectively) is given. The $\log 10$ values of the number of gentamicin protected bacteria + standard deviation are given. Results are presented as a representative experiment conducted in triplicate. Superscript $\left(^{*}\right)$ refers to a significant difference compared to the control group $(p<0.05)$.

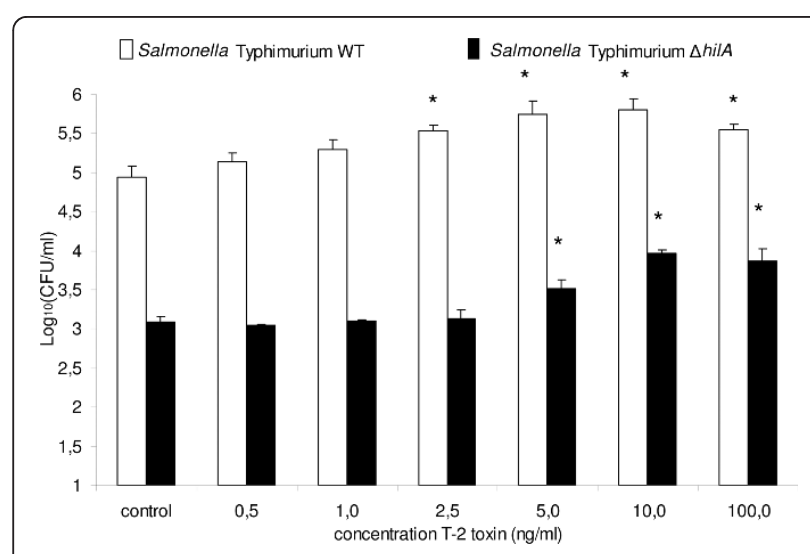

Figure 5 Effect of T-2 toxin treatment of differentiated IPEC-J2 cells, on the invasion of Salmonella Typhimurium WT and $\Delta$ hilA. The invasiveness is shown of Salmonella Typhimurium WT (white bars) and Salmonella Typhimurium $\triangle$ hilA (black bars) in differentiated IPEC-J2 cells whether or not exposed to different concentrations of T-2 toxin (0.500-100 ng/mL). The log 10 values of the number of gentamicin protected bacteria + standard deviation are given. Results are presented as a representative experiment conducted in triplicate. Superscript $\left(^{*}\right)$ refers to a significant difference compared to the control group $(p<0.05)$.

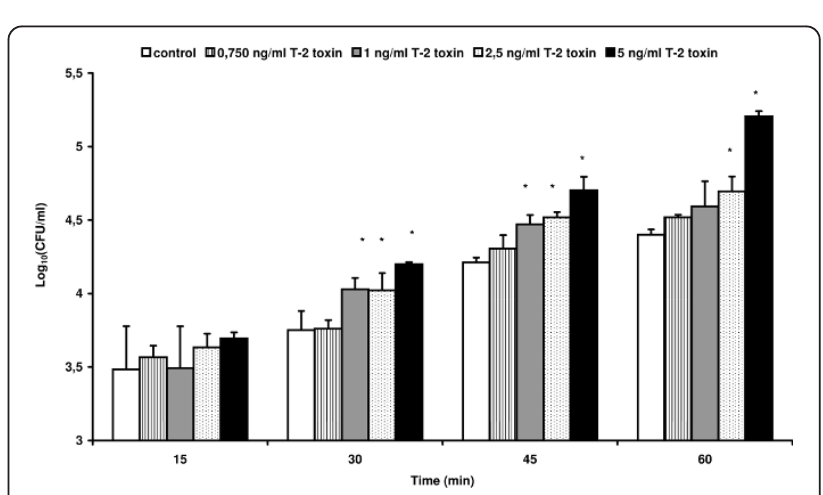

Figure 6 The influence of T-2 toxin treatment of an on IPEC-J2 monolayer on the transepithelial passage of Salmonella

Typhimurium. IPEC-J2 cells seeded onto inserts for 21 days until differentiation were either exposed to blank medium or treated with different concentrations of T-2 toxin $(0.750,1,2.5$ or $5 \mathrm{ng} / \mathrm{mL})$ for $24 \mathrm{~h}$, prior to measuring the transepithelial passage of Salmonella Typhimurium. The translocation of the bacteria was measured 15, 30, 45 and 60 min after inoculation. Results are presented as a representative experiment conducted in triplicate. Superscript $\left(^{*}\right)$ refers to a significantly higher translocation of the bacteria compared to the unexposed control wells $(p<0.05)$. 
Table 3 Differential protein expression of differentiated IPEC-J2 cells after exposure to T-2 toxin.

\begin{tabular}{|c|c|c|c|}
\hline Protein name* & Function* & $\begin{array}{l}\text { Protein ratio treated/ } \\
\text { untreated IPEC-J } 2 \text { cells on } \\
\text { the } T \text {-test approach }\end{array}$ & $\begin{array}{l}\text { Protein ratio treated/ } \\
\text { untreated IPEC-J } 2 \text { cells on } \\
\text { the } \log ^{*} \log \text { approach }\end{array}$ \\
\hline $\begin{array}{l}\text { Cytochrome c oxidase } \\
\text { subunit VIlc }\{\text { N-terminal }\}\end{array}$ & $\begin{array}{l}\text { This protein is one of the nuclear-coded polypeptide } \\
\text { chains of cytochrome c oxidase, the terminal oxidase in } \\
\text { mitochondrial electron transport. }\end{array}$ & 0.6 & 0.6 \\
\hline $\begin{array}{l}\text { Microsomal glutathione S- } \\
\text { transferase } 3\end{array}$ & Functions as a glutathione peroxidase. & 0.6 & 0.6 \\
\hline $\begin{array}{l}\text { PREDICTED: similar to } \\
\text { Keratin, type I cytoskeletal } \\
18 \text { (Cytokeratin 18) }\end{array}$ & $\begin{array}{l}\text { When phosphorylated, plays a role in filament } \\
\text { reorganization. }\end{array}$ & 0.7 & 0.7 \\
\hline $\begin{array}{l}\text { Myristoylated alanine-rich } \\
\text { C-kinase substrate }\end{array}$ & $\begin{array}{l}\text { Myristoylated alanine-rich C-kinase substrate is a } \\
\text { filamentous (F) actin cross-linking protein. }\end{array}$ & 0.7 & 0.7 \\
\hline Annexin A4 & $\begin{array}{l}\text { Calcium/phospholipid-binding protein which promotes } \\
\text { membrane fusion and is involved in exocytosis. }\end{array}$ & 0.7 & 0.7 \\
\hline $\begin{array}{l}\text { Chain A, Bovine } \\
\text { Mitochondrial F1-Atpase } \\
\text { Complexed With Aurovertin } \\
\text { B }\end{array}$ & $\begin{array}{l}\text { Mitochondrial membrane ATP synthase (F1F0 ATP } \\
\text { synthase or Complex V) produces ATP from ADP in the } \\
\text { presence of a proton gradient across the membrane. }\end{array}$ & 0.7 & 0.8 \\
\hline Protein S100-A16 & $\begin{array}{l}\text { Calcium-binding protein. Binds one calcium ion per } \\
\text { monomer. }\end{array}$ & 0.8 & 0.8 \\
\hline Putative beta-actin & $\begin{array}{l}\text { Actins are highly conserved proteins that are involved in } \\
\text { various types of cell motility and are ubiquitously } \\
\text { expressed in all eukaryotic cells. }\end{array}$ & 0.8 & 0.7 \\
\hline $\begin{array}{l}\text { Cysteine and glycine-rich } \\
\text { protein } 1 \text { isoform } 1\end{array}$ & $\begin{array}{l}\text { Encodes a member of the cysteine-rich protein (CSRP) } \\
\text { family that includes a group of LIM domain proteins, } \\
\text { which may be involved in regulatory processes important } \\
\text { for development and cellular differentiation. }\end{array}$ & 1.2 & 1.2 \\
\hline Heat shock protein 60 & $\begin{array}{l}\text { Implicated in mitochondrial protein import and } \\
\text { macromolecular assembly. }\end{array}$ & 1.2 & 1.2 \\
\hline $\begin{array}{l}\text { PREDICTED: similar to } \\
\text { nucleolin-related protein } \\
\text { isoform } 3\end{array}$ & Plays a role in different steps in ribosome biogenesis. & 1.2 & 1.2 \\
\hline $\begin{array}{l}\text { Heterogeneous nuclear } \\
\text { ribonucleoprotein F }\end{array}$ & $\begin{array}{l}\text { Component of the heterogeneous nuclear } \\
\text { ribonucleoprotein (hnRNP) complexes which provide the } \\
\text { substrate for the processing events that pre-mRNAs } \\
\text { undergo before becoming functional, translatable mRNAs } \\
\text { in the cytoplasm. }\end{array}$ & 1.2 & 1.2 \\
\hline Heat shock protein 10 & $\begin{array}{l}\text { Essential for mitochondrial protein biogenesis, together } \\
\text { with chaperonin } 60 \text {. }\end{array}$ & 1.2 & 1.2 \\
\hline Thymosin beta-10 & $\begin{array}{l}\text { Binds to and sequesters actin monomers ( } G \text { actin) and } \\
\text { therefore inhibits actin polymerization. }\end{array}$ & 1.2 & 1.2 \\
\hline $\begin{array}{l}\text { Thioredoxin-related } \\
\text { transmembrane protein } 1\end{array}$ & May participate in various redox reactions. & 1.3 & 1.3 \\
\hline Glutathione S-transferase P & $\begin{array}{l}\text { Conjugation of reduced glutathione to a wide number of } \\
\text { exogenous and endogenous hydrophobic electrophiles. }\end{array}$ & 1.3 & 1.3 \\
\hline 14-3-3 protein sigma & $\begin{array}{l}\text { Adapter protein implicated in the regulation of a large } \\
\text { spectrum of both general and specialized signalling } \\
\text { pathway. of G2/M progression. }\end{array}$ & 1.3 & 1.3 \\
\hline Elongation factor 1-beta & $\begin{array}{l}\text { Elongation factor 1-beta and Elongation factor 1-delta } \\
\text { stimulate the exchange of GDP bound to Elongation } \\
\text { factor 1-alpha to GTP. }\end{array}$ & 1.3 & 1.3 \\
\hline Profilin & $\begin{array}{l}\text { Binds to actin and affects the structure of the } \\
\text { cytoskeleton. }\end{array}$ & 1.5 & 1.5 \\
\hline $\begin{array}{l}\text { Cyclophilin A or Peptidyl- } \\
\text { prolyl cis-trans isomerase A }\end{array}$ & $\begin{array}{l}\text { Peptidyl-prolyl isomerase accelerates the folding of } \\
\text { proteins. }\end{array}$ & 1.6 & 1.6 \\
\hline $\begin{array}{l}\text { Branched-chain-amino-acid } \\
\text { aminotransferase, cytosolic }\end{array}$ & $\begin{array}{l}\text { Catalyzes the first reaction in the catabolism of the } \\
\text { essential branched chain amino acids leucine, isoleucine, } \\
\text { and valine. }\end{array}$ & 1.6 & 1.6 \\
\hline
\end{tabular}




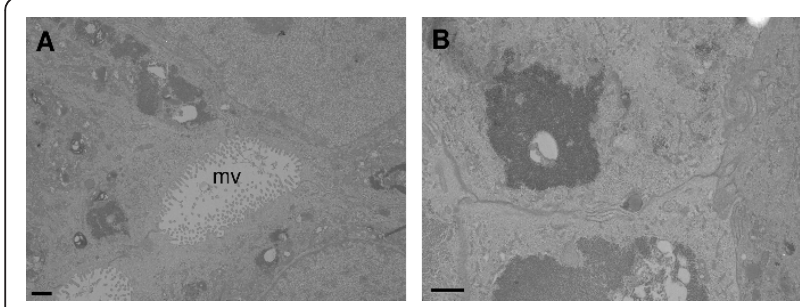

Figure 7 The effect of T-2 toxin on the morphology of differentiated IPEC-J2 cells. Transmission electron micrographs of differentiated IPEC-J2 cells fixed $24 \mathrm{~h}$ after exposure to (A) control medium or (B) $5 \mathrm{ng} / \mathrm{mL}$ T-2 toxin. These pictures serve as a representative for a confluent monolayer of IPEC-J2 cells and no differences were seen on the ultrastructure of T-2 toxin $(5 \mathrm{ng} / \mathrm{mL})$ treated IPEC-J2 cells in comparison to untreated cells. Scale bar $=$ $1 \mu \mathrm{M} ; \mathrm{mv}=$ microvilli.

multidrug efflux systems and the mar $A B$ multi-antibiotic efflux system were upregulated as were several other detoxification systems and the $y e h Y X W$ proline/glycine betaine transport systems involved in osmoprotection. Overall the transcriptomic data reveals a bacterium under stress, up-regulating stress response systems and downregulating its metabolic functions.

\section{Discussion}

The ingestion of $\mathrm{T}-2$ toxin contaminated feed by pigs resulted in a significant reduction of weight gain, after only 18 days, compared to control pigs that received blank feed (Table 1). To our knowledge, this is the first time such an effect has been reported due to a low concentration of T-2 toxin. Since contamination of human foodstuff with T-2 toxin is an emerging issue and concentrations up to $1810 \mu \mathrm{g} \mathrm{T}-2$ toxin per $\mathrm{kg}$ wheat have been reported in Germany [9], it is feasible that T-2 toxin may also affect human metabolism. Different studies describe that, at high doses, T-2 toxin affects the intestinal absorption of nutrients and reduces the daily feed intake, resulting in a reduced body weight gain [44-46]. However, due to the housing conditions of the animals, we were not able to record the daily feed intake of the animals. Therefore, we cannot conclude whether the reduced weight gain of the pigs was the result of a decreased daily feed intake.

iTRAQ analysis showed that even an extreme low concentration of $5 \mathrm{ng} / \mathrm{mL} \mathrm{T}-2$ toxin affects protein expression in differentiated IPEC-J2 cells compared to untreated cells (Table 3 ). The main mechanism by which T-2 toxin causes its toxic effects is through inhibition of protein synthesis, leading to a ribotoxic stress response. This activates c-Jun N-terminal kinase (JNK)/p38 MAPKs and as a consequence modulates numerous physiological processes including cellular homeostasis, cell growth, differentiation and apoptosis [47]. Proteomic analysis showed an upregulation of proteins involved in ribosome biogenesis, protein

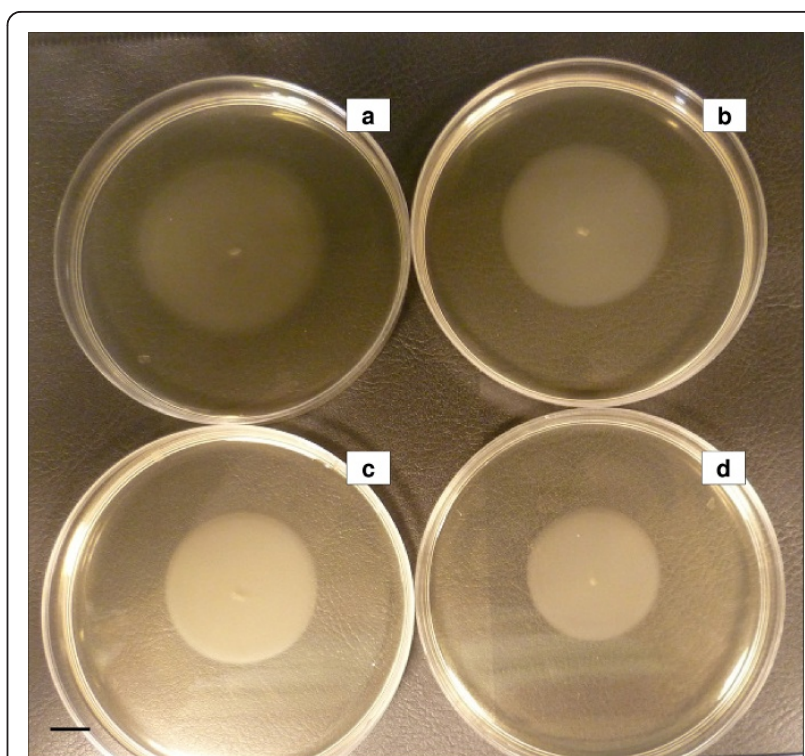

Figure 8 Effect of T-2 toxin on the swarming capacity of Salmonella Typhimurium. Swarming capacity of Salmonella Typhimurium after overnight incubation at $37^{\circ} \mathrm{C}$ on semi-solid agar plates supplemented with (a) $0 \mathrm{ng} / \mathrm{mL}$ T-2 toxin, (b) $100 \mathrm{ng} / \mathrm{mL}$ T-2 toxin, (c) $500 \mathrm{ng} / \mathrm{mL} \mathrm{T}-2$ toxin, or (d) $1000 \mathrm{ng} / \mathrm{mL} \mathrm{T}-2$ toxin. The diameter of the circle is a measure for the motility of the bacteria. Scale bar $=1 \mathrm{~cm}$.

synthesis, protein folding and c-Jun N-Terminal kinase signalling. The increased expression of these proteins could be a rescue mechanism, highlighting that even a low concentration of $5 \mathrm{ng} / \mathrm{mL} \mathrm{T}-2$ toxin leads to a ribotoxic stress response in differentiated IPEC-J2 cells. The toxic character of T-2 toxin was also shown by the upregulation of heat shock proteins, pre-mRNA splicing factor heterogeneous nuclear ribonucleoprotein $\mathrm{F}$, which could be a mechanism to increase mRNA stability [48], and 14-3-3 sigma. The protein 14-3-3 sigma is a p53-regulated inhibitor of G2/M progression [49] and its upregulation might emphasize the DNA damage caused by T-2 toxin [50]. Overall, these iTRAQ data may indicate that T-2 toxin damages the porcine enterocyte, and by doing so, harms the absorption of nutrients with a reduced weight gain as result.

In contrast to other Fusarium mycotoxins, there is no guidance value set by the European Commission for the amount of T-2 toxin in complementary and complete feed for pigs. As shown by a neutral red assay, T-2 toxin affects cell viability at very low concentrations (Figure 3 ). The in vitro viability of porcine macrophages, undifferentiated and differentiated porcine intestinal epithelial cells was significantly decreased at concentrations $\geq 1 \mathrm{ng} / \mathrm{mL}$, $\geq 2.5 \mathrm{ng} / \mathrm{mL}$ and $\geq 15 \mathrm{ng} / \mathrm{mL}$, respectively. Taking into account that such low concentrations negatively affect cell viability in vitro, and that these concentrations are 


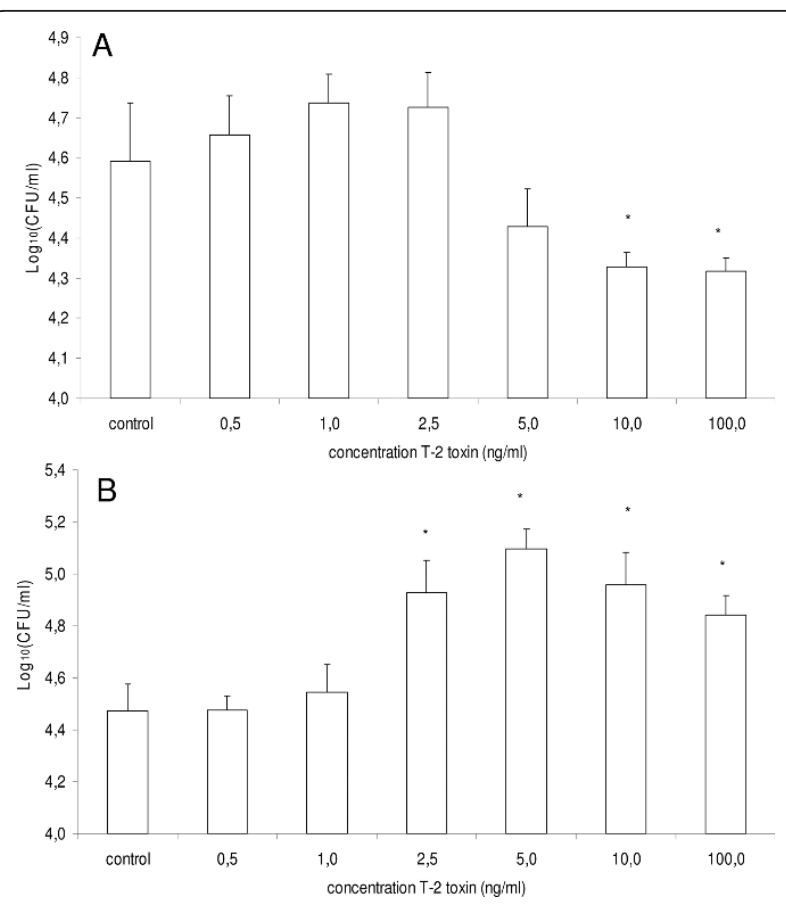

Figure 9 The influence of T-2 toxin treatment of differentiated IPEC-J2 cells and/or Salmonella Typhimurium bacteria, on the invasion in these cells. The invasiveness is shown of Salmonella Typhimurium bacteria grown for $5 \mathrm{~h}$ in LB medium with T-2 toxin (0.500-100 ng/mL), in (A) untreated differentiated IPEC-J2 cells and (B) T-2 toxin $(0.500-100 \mathrm{ng} / \mathrm{mL})$ treated differentiated IPEC-J2 cells, for $24 \mathrm{~h}$. The $\log 10$ values of the number of gentamicin protected bacteria + standard deviation are given. Results are presented as a representative experiment conducted in triplicate. Superscript $\left(^{*}\right)$ refers to a significant difference compared to the control group ( $p$ $<0.05)$.

relevant in practice $[9,23]$, it is of utmost importance that maximum levels are set for this mycotoxin as well.

Ingestion of low and relevant concentrations of T-2 toxin results in reduced numbers of Salmonella Typhimurium bacteria in the cecum contents of pigs, and a tendency to a reduced colonization of the jejunum, ileum, cecum, colon and colon contents (Figure 1). With T-2 toxin and Salmonella Typhimurium being major problems in swine industry and with salmonellosis being one of the most important zoonotic bacterial diseases in both developed and developing countries, we aimed at evaluating the effect of T-2 toxin on the pathogenesis of a Salmonella Typhimurium infection in pigs. Until now, conflicting results have been published concerning the effect of mycotoxins on the susceptibility to intestinal infections and still little is known about the effects of low concentrations of these mycotoxins [16-18,51-53]. According to Ziprin and McMurray, T-2 toxin did not affect the course of salmonellosis in mice [51]. In the present study, we provide evidence that these data cannot be extrapolated to a pig host. Since the porcine intestine shows physiological, anatomical and pathological similarities to the human gut [54], it is not unlikely that T-2 toxin similarly affects the pathogenesis of a Salmonella infection in the human host as in the pig host.

The ingestion of $15 \mu \mathrm{g}$ T-2 toxin per $\mathrm{kg}$ feed resulted in a significant decreased expression of IL-1 $\beta$ (Figure 2). Once Salmonella has invaded the intestinal epithelium, the innate immune system is triggered and the porcine gut will react with the production of several cytokines [55]. Both Salmonella and mycotoxins affect the innate immune system. Zhou et al. found that deoxynivalenol (DON) increases the expression of TGF- $\beta$ and IFN- $\gamma$ in the small intestine of mice [56]. Recently, Kruber et al. established that T-2 toxin strongly induces IL- 8 production in a Caco-2 intestinal epithelial cell line [57]. According to Vandenbroucke et al., DON and Salmonella Typhimurium synergistically potentiate intestinal inflammation in an ileal loop model of pigs [24]. As our control group is Salmonella positive, we cannot conclude whether the decreased expression of IL- $1 \beta$ in the T-2 toxin treated pigs is caused by the effects of T-2 toxin on the innate immune system, the reduced numbers of Salmonella Typhimurium in the gut, or a combination of both. Furthermore, by the use of ELISA analysis, Maresca et al. showed that DON caused a biphasic effect on IL-8 secretion by Caco-2 cells [58]. They also pointed out that this biphasic effect was not observed at mRNA level, where a dose-dependent increase in IL- 8 mRNA was noticed [58]. These data implicate that in order to obtain results about the secretion of IL-1 $\beta$, ELISA analysis on the ileum should be performed.

In order to elucidate how T-2 toxin causes reduced numbers of Salmonella Typhimurium bacteria in the cecum contents of pigs, and a tendency to a reduced colonization of the jejunum, ileum, cecum, colon and colon contents, we investigated the effects of T-2 toxin on the interactions of Salmonella Typhimurium with porcine macrophages and intestinal epithelial cells, two cell types that play an important role in the pathogenesis of a Salmonella infection. In vitro treatment of the host cells with T-2 toxin rendered them more susceptible to invasion, in a SPI-1 independent manner, and increased the transepithelial passage of the bacterium (Figures 4 and 6). This is in accordance with Vandenbroucke et al. who showed that DON promotes the invasion and translocation of Salmonella Typhimurium over porcine host cells, by a mechanism that is not SPI-1 dependent $[24,59]$. The results obtained by Maresca et al. also confirm our results since they pointed out that DON concentrations that do not compromise the barrier function, significantly increase the passage of non-invasive Escherichia coli bacteria through Caco-2 inserts [58]. As reviewed by Maresca and Fantini [60] such increase in bacterial passage through intestinal epithelial cells could 
be involved in inducing inflammatory bowel diseases. Extrapolating these results to the in vivo situation, one would expect an increased colonization by Salmonella in pigs. However, we showed that ingestion of low and relevant concentrations of $\mathrm{T}-2$ toxin resulted in a significantly decreased amount of Salmonella Typhimurium bacteria in the cecum contents and in a tendency to reduced colonization of the jejunum, ileum, cecum, colon and colon contents. In vitro, T-2 toxin decreased the intracellular survival of Salmonella Typhimurium in PAM, undifferentiated IPEC-J2 cells and differentiated IPEC-J2 cells (Figure 4) at concentrations which significantly reduced the cell viability (Figure 3). Possibly this reduced survival plays an important role in the in vivo outcome. However, whether this reduced survival is due to a decrease in viable cells, a diminished replication capacity of the bacterium or a combination of both, is unknown.

Invasion of Salmonella in nonphagocytic cells involves a series of cytoskeletal changes, characterized by actin polymerization and the formation of membrane ruffles. These cytoskeletal changes are important for the uptake and the cytoplasmic transport of the bacterium, as well as for the establishment and the stability of the bacterial replicative niche, also called Salmonella containing vacuole (SCV) [59]. By the use of iTRAQ analysis, we demonstrated that $5 \mathrm{ng} / \mathrm{mL} \mathrm{T}-2$ toxin induces alterations in the expression of proteins that are involved in the cytoskeleton formation of differentiated IPEC-J2 cells. T-2 toxin causes a decreased expression of cytokeratin 18, a member of the intermediate filament network that provides support and integrity to the cytoskeleton [61], of myristoylated alanine-rich $\mathrm{C}$-kinase substrate, a filamentous actin crosslinking protein [62] and of putative beta-actin, which is a major component of the cytoskeleton. Furthermore, T-2 toxin causes an increased expression of thymosin beta-10, an actinsequestering protein involved in cytoskeleton organization and biogenesis [63], of cysteine and glycine-rich protein 1 isoform 1, a regulator for actin filament bundling [64] and of profilin, an actin-binding protein that can sequester G-actin or actively participate in filament growth [65]. According to Vandenbroucke et al., low concentrations of DON can modulate the cytoskeleton of macrophages resulting in an enhanced uptake of Salmonella Typhimurium in porcine macrophages [59]. The observed changes in protein expression are not sufficient to induce morphological changes, as assessed with TEM (Figure 7). However, the T-2 toxin induced altered expression of cytoskeleton associated proteins could influence the interactions between IPEC-J2 cells and Salmonella. Thus T-2 toxin and Salmonella Typhimurium appear to act synergistically, inducing cytoskeleton reorganizations which increase the invasion of the bacterium.
We also examined the effects of T-2 toxin on Salmonella Typhimurium gene expression. Microarray analysis revealed that $\mathrm{T}-2$ toxin caused a general downregulation of Salmonella Typhimurium metabolism (Additional file 5) and notably of ribosome synthesis. To our knowledge, this is the first time it has been shown that $\mathrm{T}-2$ toxin affects ribosomal gene expression in both eukaryotic [66] and prokaryotic cells. Microarray analysis also showed that $\mathrm{T}-2$ toxin causes a downregulation of flagella gene expression (Additional file 5) and consequently resulted in decreased motility of Salmonella Typhimurium (Figure 8). Motility of Salmonella increases the probability that the bacterium will reach suitable sites for invasion and successful infections [67]. Transcriptomic analysis furthermore demonstrated that exposure to T-2 toxin results in reduced expression of many SPI-1 genes. According to Boyen et al., SPI-1 plays a crucial role in the invasion and colonization of the porcine gut and in the induction of influx of neutrophils [68]. Shah et al. indicated that the pathogenicity of Salmonella Enteritidis isolates is associated with both motility and secretion of the type III secretion system (TTSS) effector proteins [67]. Isolates with low invasiveness had impaired motility and impaired secretion of FlgK, FljB and FlfL or TTSS secreted SipA and SipD. Therefore, a T-2 toxin induced downregulation of SPI- 1 and motility genes and a reduced motility may lead to a reduced colonization by the bacterium in pigs.

In conclusion, we showed that the presence of low and in practice relevant concentrations of T-2 toxin in the feed causes a decrease in the amount of Salmonella Typhimurium bacteria present in the cecum contents of pigs, and a tendency to a reduced colonization of the jejunum, ileum, cecum, colon and colon contents. In vitro, T-2 toxin causes an increased invasion and transepithelial passage of the bacterium in and through $\mathrm{T}-2$ toxin treated porcine cells, in a SPI-1 independent manner. However, T-2 toxin significantly reduces the SPI-1 gene expression, invasiveness and motility of the bacterium. Therefore, in vivo, the effect of T-2 toxin on the bacterium is probably more pronounced than the host cell-mediated effect.

\section{Additional material}

Additional file 1: Composition of the blank piglet feed used in the in vivo assay.

Additional file 2: The progression of TEER values of IPEC-J2 cells, seeded at a density of $2 \times 10^{4}$ cells, on collagen coated Transwell ${ }^{\circledR \circledast}$ polycarbonate membrane inserts (pore size $=3.0 \mu \mathrm{m}$ and membrane diameter $=6.5 \mathrm{~mm}$ ). (TIFF $78 \mathrm{~kb}$ ).

Additional file 3: TEER values of IPEC-J2 cells, 21 days after seeding them at density of $2 \times 10^{4}$ cells, on collagen coated Transwell ${ }^{\mathbb{B}_{\circledast}}$ polycarbonate membrane inserts. After 21 days, the cells were exposed to different concentrations of T-2 toxin ranging from 0 to $5 \mathrm{ng}$ / $\mathrm{mL}$, during $24 \mathrm{~h}$. 
Additional file 4: Effect of T-2 toxin on the growth of Salmonella Typhimurium. The $\log 10$ values of the $\mathrm{CFU} / \mathrm{mL}+$ standard deviation are given at different time points $(t=0,2.5,5,7.5,24 \mathrm{~h})$. Salmonella Typhimurium growth was examined in LB medium, whether or not supplemented with T-2 toxin $(0.04-20 \mu \mathrm{g} / \mathrm{mL})$. Results are presented as a representative experiment conducted in triplicate.

Additional file 5: Gene expression comparison between a logarithmic phase culture of Salmonella Typhimurium whether or not exposed to T-2 toxin. Microarray data of a logarithmic phase culture of Salmonella Typhimurium grown in presence or absence of 5 $\mathrm{ng} / \mathrm{mL} \mathrm{T}-2$ toxin, showing genes differentially downregulated, by $\geq 1.5$ fold with $p \leq 0.05$.

Additional file 6: Gene expression comparison between a logarithmic phase culture of Salmonella Typhimurium whether or not exposed to T-2 toxin. Microarray data of a logarithmic phase culture of Salmonella Typhimurium grown in presence or absence of 5 $\mathrm{ng} / \mathrm{mL} \mathrm{T}-2$ toxin, showing genes differentially upregulated, by $\geq 1.5$ fold with $p \leq 0.05$.

\section{Acknowledgements}

This work was supported by the Institute for the Promotion of Innovation by Science and Technology in Flanders (IWT Vlaanderen), Brussels, Belgium [IWT Landbouw 70574]. The IPEC-J2 cell line was a kind gift of Dr Schierack, Institut für Mikrobiologie und Tierseuchen, Berlin, Germany. The technical assistance of Anja Van den Bussche is greatly appreciated.

\section{Author details}

${ }^{1}$ Department of Pathology, Bacteriology and Avian Diseases, Faculty of Veterinary Medicine, Ghent University, 9820 Merelbeke, Belgium.

${ }^{2}$ Department of Pharmacology, Toxicology and Biochemistry, Faculty of Veterinary Medicine, Ghent University, 9820 Merelbeke, Belgium.

${ }^{3}$ Department of Pharmaceutics, Faculty of Pharmaceutical Sciences, Ghent University, 9000 Ghent, Belgium. ${ }^{4}$ Department of Foodborne Bacterial Pathogens, Institute of Food Research, Norwich Research Park, NR4 7UA Norwich, UK. ${ }^{5}$ Department of Bioanalysis, Faculty of Pharmaceutical Sciences, Ghent University, 9000 Ghent, Belgium. ${ }^{6}$ Department of Food Science and Technology, Faculty of Applied bioengineering, University College Ghent, 9000 Ghent, Belgium. 'Department of Basic Medical Sciences, Faculty of Medicine and Health Sciences, Ghent University, 9000 Ghent, Belgium.

\section{Authors' contributions}

EV, AT and NS performed the microarray analysis. EV and KD carried out the TEM analysis. EV, MD and DD performed the ITRAQ analysis. EV, AVP, W, JG and $B L$ executed the animal experiments. The T-2 toxin contaminated feed was prepared by EV, W and ME and the concentration of T-2 toxin in the feed was determined by SDS. EV, FB, FH, PDB, SC and FP conceived the study, participated in its design and coordination. EV, SC and FP co-drafted the manuscript. W and MD share second authorship, SC and FP share senior authorship. All authors read and approved the final manuscript.

\section{Competing interests}

Sources of financial support have been acknowledged and the authors declare that they have no competing interests.

Received: 4 November 2011 Accepted: 22 March 2012

Published: 22 March 2012

\section{References}

1. Moss MO: Mycotoxin review-2. Fusarium. Mycologist 2002, 16:157-161.

2. Placinta C, D'Mello J, Macdonald A: A review of worldwide contamination of cereal grains and animal feed with Fusarium mycotoxins. Anim Feed Sci Tech 1999, 78:21-37.

3. Gutleb AC, Morrison E, Murk AJ: Cytotoxicity assays for mycotoxins produced by Fusarium strains: a review. Environ Toxicol Pharmacol 2002, 11:309-320.

4. Hussein HS, Brasel JM: Toxicity, metabolism, and impact of mycotoxins on humans and animals. Toxicology 2001, 167:101-134.
5. Wu Q, Dohnal V, Huang L, Kuca K, Yuan Z: Metabolic pathways of trichothecenes. Drug Metab Rev 2010, 42:250-267.

6. Wang ZG, Feng JN, Tong Z: Human toxicosis caused by moldy rice contaminated with Fusarium and T-2 toxin. Biomed Environ Sci 1993, 6:65-70.

7. Scientific committee on Food: Opinion of the Scientific Committee on Food on Fusarium Toxins. Part 5: T-2 toxin and HT-2 toxin. 2001 [http:// ec.europa.eu/food/fs/sc/scf/out88_en.pdf], SCF/CS/SCTM/MYC/25 Rev 6 Final.

8. European Food Safety Authority: Scientific opinion on the risk for animal and public health related to the presence of T-2 and HT-2 toxin in food and feed. EFSA J 2011, 9:2481.

9. Schollenberger M, Müller HM, Rüfle M, Suchy S, Plank S, Drochner W: Natural occurrence of 16 Fusarium toxins in grains and feedstuffs of plant origin from Germany. Mycopathologia 2006, 161:43-52.

10. European Food Safety Authority: European summary report on trends and sources of zoonoses and zoonotic agents and food-agents and foodborne outbreaks 2009. EFSA J 2009, 9:378.

11. Wood RL, Pospischil A, Rose R: Distribution of persistent Salmonella Typhimurium infection in internal organs of swine. Am J Vet Res 1989, 50:1015-1021.

12. Majowicz SE, Musto J, Scallan E, Angulo FJ, Kirk M, O'Brien SJ, Jones TF, Fazil A, Hoekstra RM: The global burden of nontyphoidal Salmonella gastroenteritis. Clin Infect Dis 2010, 50:882-889.

13. Cavret S, Lecoeur S: Fusariotoxin transfer in animal. Food Chem Toxicol 2006, 44:444-453.

14. Rafai P, Tuboly S, Bata A, Tilly P, Ványi A, Papp Z, Jakab L, Túry E: Effect of various levels of $\mathrm{T}-2$ toxin in the immune system of growing pigs. Vet Rec 1995, 136:511-514.

15. Kankkunen P, Rintahaka J, Aalto A, Leino M, Majuri ML, Alenius H, Wolff $H$, Matikainen S: Trichothecene mycotoxins activate inflammatory response in human macrophages. J Immunol 2009, 182:6418-6425.

16. Tenk I, Fodor E, Szathmáry C: The effect of pure Fusarium toxins (T-2, F-2, DAS) on the microflora of the gut and on plasma glucocorticoid levels in rat and swine. Zentralbl Bakteriol Mikrobiol Hyg A 1982, 252:384-393.

17. Tai JH, Pestka JJ: Impaired murine resistance to Salmonella Typhimurium following oral exposure to the trichothecene T-2 toxin. Food Chem Toxicol 1988, 26:691-698.

18. Oswald IP, Desautels C, Laffitte J, Fournout S, Peres SY, Odin M, Le Bars P, Le Bars J, Fairbrother JM: Mycotoxin fumonisin B1 increases intestinal colonization by pathogenic Escherichia coli in pigs. Appl Environ Microbiol 2003, 69:5870-5874.

19. Tanguy M, Burel C, Pinton P, Guerre P, Grosjean F, Queguiner M, Cariolet R, Tardieu D, Rault JC, Oswald IP, Fravalo P: Effets des fumonisines sur la santé du porc: sensibilité aux salmonelles et statut immunitaire. Journées de la Recherche Porcine 2006, 38:393-398, (in French).

20. Boyen F, Pasmans F, Van Immerseel F, Morgan E, Botteldoorn N, Heyndrickx M, Volf J, Favoreel H, Hernalsteens JP, Ducatelle R, Haesebrouck F: A limited role for SsrA/B in persistent Salmonella Typhimurium infections in pigs. Vet Microbiol 2008, 128:364-373.

21. Boyen F, Pasmans F, Donné E, Van Immerseel F, Adriaensen C, Hernalsteen J-P, Ducatelle R, Haesebrouck F: Role of SPI-1 in the interactions of Salmonella Typhimurium with porcine macrophages. Vet Microbiol 2006, 113:35-44.

22. Lundberg U, Vinatzer U, Berdnik D, von Gabain A, Baccarini M: Growth phase-regulated induction of Salmonella-induced macrophage apoptosis correlates with transient expression of SPI-1 genes. J Bacteriol 1999, 181:3433-3437.

23. Monbaliu S, Van Poucke C, Detavernier C, Dumoulin F, Van De Velde M, Schoeters E, Van Dyck S, Averkieva O, Van Peteghem C, De Saeger S: Occurrence of mycotoxins in feed as analyzed by a multi-mycotoxin LCMS/MS method. J Agric Food Chem 2010, 58:66-71.

24. Vandenbroucke V, Croubels S, Martel A, Verbrugghe E, Goossens J, Van Deun K, Boyen F, Thompson A, Shearer N, De Backer P, Haesebrouck F, Pasmans F: The mycotoxin deoxynivalenol potentiates intestinal inflammation by Salmonella Typhimurium in porcine ileal loops. PLOS One 2011, 6:e23871.

25. Bouaziz C, Abid-Essefi S, Bouslimi A, El Golli E, Bacha H: Cytotoxicity and related effects of T-2 toxin on cultured Vero cells. Toxicon 2006, 48:343-352. 
26. Verbrugghe E, Boyen F, Van Parys A, Van Deun K, Croubels S, Thompson A, Shearer N, Leyman B, Haesebrouck F, Pasmans F: Stress induced Salmonella Typhimurium recrudescence in pigs coincides with cortisol induced increased intracellular proliferation in macrophages. Vet Res 2011, 42:118.

27. Ross PL, Huang YN, Marchese JN, Williamson B, Parker K, Hattan S, Khainovski N, Pillai S, Dey S, Daniels S, Purkayastha S, Juhasz P, Martin S, Bartlet-Jones M, He F, Jacobson A, Pappin DJ: Multiplexed protein quantitation in Saccharomyces cerevisiae using amine-reactive isobaric tagging reagents. Mol Cell Proteomics 2004, 3:1154-1169.

28. Bijttebier J, Tilleman K, Deforce D, Dhaenens M, Van Soom A, Maes D: Proteomic study to identify factors in follicular fluid and/or serum involved in in vitro cumulus expansion of porcine oocytes. Soc Reprod Fertil Supp/ 2009, 66:205-206.

29. Colaert N, Van Huele C, Degroeve S, Staes A, Vandekerckhove J, Gevaert K, Martens $L$ : Combining quantitative proteomics data processing workflows for greater sensitivity. Nat Methods 2011, 8:481-483.

30. Nagy G, Danino V, Dobrindt U, Pallen M, Chaudhuri R, Emödy L, Hinton JC, Hacker J: Downregulation of key virulence factors makes the Salmonella enterica serovar Typhimurium rfaH mutant a promising live-attenuated vaccine candidate. Infect Immun 2006, 74:5914-5925.

31. Edgar R, Domrachev M, Lash AE: Gene Expression Omnibus: NCBI gene expression and hybridization array data repository. Nucleic Acids Res 2002, 30:207-210.

32. Gene Expression Omnibus. [http://www.ncbi.nlm.nih.gov/geo/query/acc. cgi?acc=GSE30925].

33. UniProtKB/Swiss-Prot protein sequence database. [http://expasy.org/ sprot/].

34. Ginisty $H$, Sicard $H$, Roger $B$, Bouvet $P$ : Structure and functions of nucleolin. J Cell Sci 1999, 112:761-772

35. Hayano T, Takahashi N, Kato S, Maki N, Suzuki M: Two distinct forms of peptidylprolyl-cis-trans-isomerase are expressed separately in periplasmic and cytoplasmic compartments of Escherichia coli cells. Biochemistry 1991, 30:3041-3048.

36. Carr-Schmid A, Valente L, Loik VI, Williams T, Starita LM, Kinzy TG: Mutations in elongation factor 1beta, a guanine nucleotide exchange factor, enhance translational fidelity. Mol Cell Biol 1999, 19:5257-5266.

37. Wang T, Arifoglu P, Ronai Z, Tew KD: Glutathione S-transferase P1-1 (GSTP1-1) inhibits C-Jun N-terminal kinase (JNK1) signaling through interaction with the C terminus. J Biol Chem 2001, 276:20999-21003.

38. Li B, Dedman JR, Kaetzel MA: Intron disruption of the annexin IV gene reveals novel transcripts. J Biol Chem 2003, 278:43276-43283.

39. Iwahashi $\mathrm{Y}$, Kitagawa $\mathrm{E}$, Iwahashi $\mathrm{H}$ : Analysis of mechanisms of $\mathrm{T}-2$ toxin toxicity using yeast DNA microarrays. Int J Mol Sci 2008, 9:2585-2600.

40. Van Raaij MJ, Abrahams JP, Leslie AG, Walker JE: The structure of bovine F1ATPase complexed with the antibiotic inhibitor aurovertin B. Proc Natl Acad Sci USA 1996, 93:6913-6917.

41. Thameem F, Yang X, Permana PA, Wolford JK, Bogardus C, Prochazka M: Evaluation of the microsomal glutathione S-transferase 3 (MGST3) locus on 1q23 as a Type 2 diabetes susceptibility gene in Pima Indians. Hum Genet 2003, 113:353-358.

42. Heizmann CW, Fritz G, Schäfer BW: S100 proteins: structure, functions and pathology. Front Biosci 2002, 7:d1356-d1368.

43. Sturchler E, Cox JA, Durussel I, Weibel M, Heizmann CW: S100A16, a novel calcium-binding protein of the EF-hand superfamily. J Biol Chem 2006, 281:38905-38917.

44. Harvey RB, Kubena LF, Huff WE, Corrier DE, Rottinghaus GE, Phillips TD: Effects of treatment of growing swine with aflatoxin and T-2 toxin. Am J Vet Res 1990, 51:1688-1693.

45. Harvey RB, Kubena LF, Elissalde MH, Rottinghaus GE, Corrier DE: Administration of ochratoxin A and T-2 toxin to growing swine. Am J Vet Res 1994, 55:1757-1761.

46. Rafai P, Bata A, Ványi A, Papp Z, Brydl E, Jakab L, Tuboly S, Túry E: Effect of various levels of T-2 toxin on the clinical status, performance and metabolism of growing pigs. Vet Rec 1995, 136:485-489.

47. Shifrin Vl, Anderson P: Trichothecene mycotoxins trigger a ribotoxic stress response that activates c-Jun $\mathrm{N}$-terminal kinase and p38 mitogenactivated protein kinase and induces apoptosis. J Biol Chem 1999, 274:13985-13992.
48. Yang $H$, Chung DH, Kim YB, Choi YH, Moon Y: Ribotoxic mycotoxin deoxynivalenol induces G2/M cell cycle arrest via p21Cip/WAF1 mRNA stabilization in human epithelial cells. Toxicology 2008, 243:145-154.

49. Hermeking $H$, Lengauer $C$, Polyak K, He TC, Zhang L, Thiagalingam S, Kinzler KW, Vogelstein B: 14-3-3 sigma is a p53-regulated inhibitor of G2/ M progression. Mol Cell 1997, 1:3-11.

50. DiPaola RS: To arrest or not to G(2)-M Cell-cycle arrest. Clin Cancer Res 2002, 8:3311-3314.

51. Ziprin RL, McMurray DN: Differential effect of T-2 toxin on murine host resistance to three facultative intracellular bacterial pathogens: Listeria monocytogenes, Salmonella Typhimurium, and Mycobacterium bovis. Am J Vet Res 1988, 49:1188-1192.

52. Kubena LF, Bailey RH, Byrd JA, Young CR, Corrier DE, Stanker LH, Rottinghaust GE: Cecal volatile fatty acids and broiler chick susceptibility to Salmonella Typhimurium colonization as affected by aflatoxins and T2 toxin. Poult Sci 2001, 80:411-417.

53. Waché YJ, Valat C, Postollec G, Bougeard S, Burel C, Oswald IP, Fravalo P: Impact of deoxynivalenol on the intestinal microflora of pigs. Int J $\mathrm{Mol}$ Sci 2009, 10:1-17.

54. Almond G: Research applications using pigs. Vet Clin North Am Food Anim Pract 1996, 12:707-716

55. Skjolaas KA, Burkey TE, Dritz SS, Minton JE: Effects of Salmonella enterica serovars Typhimurium (ST) and Choleraesuis (SC) on chemokine and cytokine expression in swine ileum and jejunal epithelial cells. Vet Immunol Immunopathol 2006, 111:199-209.

56. Zhou HR, Yan D, Pestka JJ: Induction of cytokine gene expression in mice after repeated and subchronic oral exposure to vomitoxin (Deoxynivalenol): differential toxin-induced hyporesponsiveness and recovery. Toxicol Appl Pharmacol 1998, 51:347-358.

57. Kruber P, Trump S, Behrens J, Lehmann I: T-2 toxin is a cytochrome P450 $1 \mathrm{~A} 1$ inducer and leads to MAPK/p38- but not aryl hydrocarbon receptor-dependent interleukin-8 secretion in the human intestinal epithelial cell line Caco-2. Toxicology 2011, 284:34-41.

58. Maresca M, Yahi N, Younès-Sakr L, Boyron M, Caporiccio B, Fantini J: Both direct and indirect effects account for the pro-inflammatory activity of enteropahogenic mycotoxins on the human intestinal epithelium: Stimulation of interleukin- 8 secretion, potentiation of interleukin- $1 \beta$ effect and increase in the transepithelial passage of commensal bacteria. Toxicol Appl Pharmacol 2008, 228:84-92.

59. Vandenbroucke V, Croubels S, Verbrugghe E, Boyen F, De Backer P, Ducatelle R, Rychlik I, Haesebrouck F, Pasmans F: The mycotoxin deoxynivalenol promotes uptake of Salmonella Typhimurium in porcine macrophages, associated with ERK1/2 induced cytoskeleton reorganization. Vet Res 2009, 40:64.

60. Maresca M, Fantini J: Some food-associated mycotoxins as potential risk factors in humans predisposed to chronic intestinal inflammatory diseases. Toxicon 2010, 56:282-294.

61. Singh S, Gupta PD: Tampering with cytokeratin expression results in cell dysfunction. Epithelial Cell Biol 1994, 3:79-83.

62. Hartwig JH, Thelen M, Rosen A, Janmey PA, Nairn AC, Aderem A: MARCKS is an actin filament crosslinking protein regulated by protein kinase $C$ and calcium-calmodulin. Nature 1992, 356:618-622.

63. Sribenja S, Li M, Wongkham S, Wongkham C, Yao Q, Chen C: Advances in thymosin beta10 research: differential expression, molecular mechanisms, and clinical implications in cancer and other conditions. Cancer Invest 2009, 27:1016-1022.

64. Tran TC, Singleton C, Fraley TS, Greenwood JA: Cysteine-rich protein 1 (CRP1) regulates actin filament bundling. BMC Cell Biol 2005, 6:45.

65. Gutsche-Perelroizen I, Lepault J, Ott A, Carlier MF: Filament assembly from profilinactin. J Biol Chem 1999, 274:6234-6243.

66. Van Kol SW, Hendriksen PJ, van Loveren H, Peijnenburg A: The effects of deoxynivalenol on gene expression in the murine thymus. Toxicol Appl Pharmacol 2011, 250:299-311.

67. Shah DH, Zhou X, Addwebi T, Davis MA, Orfe L, Call DR, Guard J, Besser TE: Cell invasion of poultry-associated Salmonella enterica serovar Enteritidis isolates is associated with pathogenicity, motility and proteins secreted by the type III secretion system. Microbiology 2011, 157:1428-1445. 
68. Boyen F, Pasmans F, Van Immerseel F, Morgan E, Adriaensen C,

Hernalsteens JP, Decostere A, Ducatelle R, Haesebrouck F: Salmonella

Typhimurium SPI-1 genes promote intestinal but not tonsillar colonization in pigs. Microbes Infect 2006, 8:2899-2907.

doi:10.1186/1297-9716-43-22

Cite this article as: Verbrugghe et al:: T-2 toxin induced Salmonella

Typhimurium intoxication results in decreased Salmonella numbers in

the cecum contents of pigs, despite marked effects on Salmonella-host cell interactions. Veterinary Research 2012 43:22.

Submit your next manuscript to BioMed Central and take full advantage of:

- Convenient online submission

- Thorough peer review

- No space constraints or color figure charges

- Immediate publication on acceptance

- Inclusion in PubMed, CAS, Scopus and Google Scholar

- Research which is freely available for redistribution

Submit your manuscript at 